\title{
Synergistic Interferon-Alpha-Based Combinations for Treatment of SARS-CoV-2 and Other Viral Infections
}

\author{
Aleksandr Ianevski ${ }^{1}$, Rouan Yao ${ }^{1}$, Eva Zusinaite ${ }^{2}$, Laura Sandra Lello ${ }^{2}$, Sainan Wang ${ }^{2}$, Eunji Jo ${ }^{3}$, Jaewon Yang ${ }^{3}$, \\ Erlend Ravlo ${ }^{1}$, Wei Wang ${ }^{1}$, Hilde Lysvand ${ }^{1}$, Kirsti Løseth ${ }^{1}$, Valentyn Oksenych 1(D), Tanel Tenson ${ }^{2}$ (D), \\ Marc P. Windisch ${ }^{3}$, Minna M. Poranen ${ }^{4}\left(\mathbb{D}\right.$, Anni I. Nieminen ${ }^{5}$, Svein Arne Nordbo ${ }^{1,6} \mathbb{D}_{\text {, }}$ \\ Mona Høysæter Fenstad 1,7 (D), Gunnveig Grødeland 8,9,10, Pål Aukrust 8,9,10, Marius Trøseid 8,9,10 (D), Anu Kantele 11, \\ Eglè Lastauskienè ${ }^{12} \mathbb{D}$, Astra Vitkauskienè ${ }^{13}$, Nicolas Legrand ${ }^{14}$, Andres Merits ${ }^{2}$, Magnar Bjørås ${ }^{1}$ (D) \\ and Denis E. Kainov 1,2,5,*iD
}

\section{check for} updates

Citation: Ianevski, A.; Yao, R.; Zusinaite, E.; Lello, L.S.; Wang, S.; Jo, E.; Yang, J.; Ravlo, E.; Wang, W.; Lysvand, H.; et al. Synergistic Interferon-alpha-Based Combinations for Treatment of SARS-CoV-2 and Other Viral Infections. Viruses 2021, 13, 2489. https://doi.org/10.3390/ v13122489

Academic Editors: Craig E. Cameron and Ester Ballana Guix

Received: 12 November 2021 Accepted: 8 December 2021 Published: 11 December 2021

Publisher's Note: MDPI stays neutral with regard to jurisdictional claims in published maps and institutional affiliations.

Copyright: (c) 2021 by the authors. Licensee MDPI, Basel, Switzerland. This article is an open access article distributed under the terms and conditions of the Creative Commons Attribution (CC BY) license (https:/ / creativecommons.org/licenses/by/ $4.0 /)$.
1 Department of Clinical and Molecular Medicine (IKOM), Norwegian University of Science and Technology, 7028 Trondheim, Norway; aleksandr.ianevski@ntnu.no (A.I.); rouan.yao@ntnu.no (R.Y.); erlend.ravlo@ntnu.no (E.R.); wei.wang@ntnu.no (W.W.); hilde.lysvand@ntnu.no (H.L.); kirsti.loseth@ntnu.no (K.L.); valentyn.oksenych@ntnu.no (V.O.); svein.a.nordbo@ntnu.no (S.A.N.); mona.hoyseter.fenstad@stolav.no (M.H.F.); magnar.bjoras@ntnu.no (M.B.)

2 Institute of Technology, University of Tartu, 50411 Tartu, Estonia; eva.zusinaite@ut.ee (E.Z.); laura.lello@ut.ee (L.S.L.); sainan.wang@ut.ee (S.W.); tanel.tenson@ut.ee (T.T.); andres.merits@ut.ee (A.M.)

3 Applied Molecular Virology Laboratory, Institut Pasteur Korea, Seongnam-si 463-400, Gyeonggi-do, Korea; eunji.jo@ip-korea.org (E.J.); jaewon.yang@ip-korea.org (J.Y.); marc.windisch@ip-korea.org (M.P.W.)

4 Molecular and Integrative Biosciences Research Programme, Faculty of Biological and Environmental Sciences, University of Helsinki, 00014 Helsinki, Finland; minna.poranen@helsinki.fi

5 Institute for Molecular Medicine Finland, University of Helsinki, 00014 Helsinki, Finland; anni.nieminen@helsinki.fi

6 Department of Medical Microbiology, St. Olavs Hospital, 7006 Trondheim, Norway

7 Department of Immunology and Transfusion Medicine, St. Olavs Hospital, 7006 Trondheim, Norway

8 Research Institute of Internal Medicine, Oslo University Hospital Rikshospitalet, 0372 Oslo, Norway; gunnveig.grodeland@medisin.uio.no (G.G.); paukrust@ous-hf.no (P.A.); marius.troseid@medisin.uio.no (M.T.)

9 Institute of Clinical Medicine (KlinMed), University of Oslo, 0318 Oslo, Norway

10 Section of Clinical Immunology and Infectious Diseases, Oslo University Hospital Rikshospitalet, 0372 Oslo, Norway

11 Inflammation Center, Infectious Diseases, Helsinki University Hospital, 00029 Helsinki, Finland; anu.kantele@helsinki.fi

12 Life Sciences Center, Vilnius University, 10257 Vilnius, Lithuania; egle.lastauskiene@gf.vu.lt

13 Department of Laboratory Medicine, Lithuanian University of Health Science, 44307 Kaunas, Lithuania; astra.vitkauskiene@kaunoklinikos.lt

14 Oncodesign, 25 Avenue du Québec, 91140 Villebon Sur Yvette, France; nlegrand@oncodesign.com

* Correspondence: denis.kainov@ntnu.no; Tel.: +358-405490220

Abstract: Background: There is an urgent need for new antivirals with powerful therapeutic potential and tolerable side effects. Methods: Here, we tested the antiviral properties of interferons (IFNs), alone and with other drugs in vitro. Results: While IFNs alone were insufficient to completely abolish replication of severe acute respiratory syndrome coronavirus 2 (SARS-CoV-2), IFN $\alpha$, in combination with remdesivir, EIDD-2801, camostat, cycloheximide, or convalescent serum, proved to be more effective. Transcriptome and metabolomic analyses revealed that the IFN $\alpha$-remdesivir combination suppressed SARS-CoV-2-mediated changes in Calu-3 cells and lung organoids, although it altered the homeostasis of uninfected cells and organoids. We also demonstrated that IFN $\alpha$ combinations with sofosbuvir, telaprevir, NITD008, ribavirin, pimodivir, or lamivudine were effective against HCV, $\mathrm{HEV}$, FLuAV, or HIV at lower concentrations, compared to monotherapies. Conclusions: Altogether, our results indicated that IFN $\alpha$ can be combined with drugs that affect viral RNA transcription, protein synthesis, and processing to make synergistic combinations that can be attractive targets for further pre-clinical and clinical development against emerging and re-emerging viral infections. 
Keywords: interferon-alpha; antiviral drug combination; SARS-CoV-2; hepatitis C virus; hepatitis E virus; influenza A virus; human immunodeficiency virus

\section{Introduction}

Viral diseases continue to pose a serious threat to public health, due to a paucity of effective, rapidly deployable, and widely available control measures [1-3]. When viruses infect the cells, viral pathogen-associated molecular patterns (PAMPs) are recognized, and signals are transduced to activate intrinsic and extrinsic immune responses [4]. Pattern recognition receptors (PRRs) sense incoming viruses, and activate transcription of certain IFN genes via NF-kB and other pathways. IFNs launch expression of IFN-stimulated genes (ISGs) in infected cells, as well as in nearby non-infected cells, protecting them from potential viral invasion. This activation of the innate immune response, combined with contributions from the adaptive immune response in the host, are often sufficient for elimination of most viruses [5].

IFNs are a large class of host proteins that are classified according to the cellular receptor to which they bind [6-8] (Figure S1). Type I IFNs consist of IFN-alpha (IFN $\alpha$ ), IFNbeta, IFN-epsilon, IFN-kappa, and IFN-omega, and bind to the IFN-alpha/beta receptor IFNAR1/2. Type II IFNs consist of IFN-gamma, and interact with the IFN-gamma receptor IFNGR1/2. Type III IFNs, consisting of IFN-lambda-1-4, activate downstream signaling by forming a receptor complex, together with interleukin 10 receptor 2 and the IFN-lambda receptor [9].

Type I IFNs induce transcription of different sets of ISGs, which participate in intrinsic antiviral and extrinsic immune responses. For example, ISGs like IFIT1 and OASL activate ribonuclease L (RNaseL), which leads to the degradation of viral RNA [10]. Moreover, ISGs such as interleukins, and C-X-C and C-C motif chemokines (CXCLs and CCLs) recruit immune cells to the site of infection. Notably, mutations in IFNsignaling pathway genes have resulted in increased susceptibility to viral infections and reduced patient survival [11-14]. However, the exact role of each IFN pathway and their crosstalk remain unclear.

The use of recombinant human IFNs (rhIFNs) has been approved for treatment of hepatitis C virus (HCV) and hepatitis B virus (HBV) infections [15,16]. Additionally, IFNs have been shown to be effective against a variety of other viruses, including SARS-CoV-2 in clinical trials and in laboratory settings (Figure S2) [17-21]. Unfortunately, rhIFNs possess limited efficacy when administered as antiviral treatments [22,23], and can cause adverse effects when used at established doses [24].

The toxicity of rhIFNs can be reduced by combining them with other antiviral drugs that act synergistically, thus allowing for the use of smaller doses of each component (Figure S3). Moreover, synergistic combinations can often have higher efficacy against viral infections than individual components administered as monotherapies, even at lower doses [25]. Indeed, the combination of IFN $\alpha$ and ribavirin has been approved for treatment of chronic HCV infection for more than a decade [15]. Similarly, several rhIFN-based drug combinations have been tested against COVID-19. Of note, IFNb1b-lopinavir-ritonavirribavirin, IFN $\alpha 2 \mathrm{~b}-\mathrm{IFNg}$, and IFN $\alpha$-umifenovir were all shown to be effective for treatment of patients with COVID-19 [26-29]. However, despite these promising data, the mode in which IFNs can be optimally combined with other drugs to maximize antiviral efficacy and minimize side effects remains unclear.

Here, we report several synergistic IFN $\alpha$-based combination therapies that have better efficacy and lower toxicity than single drugs against SARS-CoV-2, HCV, HEV, FluAV, and HIV-1 infections in vitro. These combinations have powerful treatment potential, which can be leveraged for use in response to wild type viruses and their immune-evading or drug-resistant variants. 


\section{Materials and Methods}

\subsection{Drugs, Viruses, Cells, and Lung Organoids}

All experiments with viruses were performed in BSL2 or BSL3 laboratories, in compliance with the guidelines of the national authorities, and under appropriate ethical and safety approvals. Standard operational procedures were approved by the institutional safety committee.

Table S1 lists IFNs and other antiviral agents, their suppliers, and catalogue numbers. Lyophilized IFNs were dissolved in sterile deionized water to obtain $200 \mu \mathrm{g} / \mathrm{mL}$ concentrations. Compounds were dissolved in dimethyl sulfoxide (DMSO; Sigma-Aldrich, Hamburg, Germany) or Milli-Q water to obtain $10 \mathrm{mM}$ stock solutions. The convalescent serum (G614) from a recovered COVID-19 patient has been described in a previous study [30].

The propagation of wild-type SARS-CoV-2 (hCoV-19/Norway/Trondheim-S15/2020), human influenza A/Udorn/307/1972 (H3N2), HCV, and HIV-1, and engineering of recombinant mCherry-expressing SARS-CoV-2 strains (SARS-CoV-2-mCherry) have been described previously [25,30-34]. To quantitate the production of infectious virions, we titered the viruses using plaque assays or ELISA [25,30-33]. A plasmid harboring a subgenomic HEV sequence, coupled with a GFP reporter gene (Kernow-C1 p6 clone, gt3; GenBank Accession No. JQ679013) were used to generate HEV transcripts. Viral-capped RNAs were transcribed in vitro from a linearized plasmid using an mMESSAGE mMACHINE ${ }^{\mathrm{TM}}$ T7 Transcription Kit (Thermo Fisher, Waltham, MA, USA). A quantity of $1.5 \times 10^{7}$ Huh-7.5 cells $/ \mathrm{mL}$ in $400 \mu \mathrm{L}$ of MaxCyte electroporation buffer were electroporated with $10 \mu \mathrm{g}$ of p6-GFP subgenomic HEV RNA. Electroporation was carried out with a Gene Pulser system (Bio-Rad, Munich, Germany) and allowed to recover for $30 \mathrm{~min}$ in a $37^{\circ} \mathrm{C}$ incubator. Recovered cells were resuspended in $10 \mathrm{~mL}$ prewarmed DMEM complete medium and maintained in an incubator for $24 \mathrm{~h}$.

The lung organoids (LOs) were generated as described previously [35]. Briefly, induced pluripotent stem cells (IPSCs) were subjected to embryoid body induction using embryoid bodies (EB)/primitive streak media (10 $\mu \mathrm{M} \mathrm{Y-27632} \mathrm{and} 3 \mathrm{ng} / \mathrm{mL}$ BMP4 in serum-free differentiation (SFD) media consisting of $375 \mathrm{~mL}$ Iscove's Modified Dulbecco's Medium (IMDM), 100 mL Ham's F-12, 2.5 mL N2, 5 mL B27, 3.75 mL 7.5\% BSA, 5 mL 1\% penicillin-streptomycin, $5 \mathrm{~mL}$ GlutaMAX, $50 \mu \mathrm{g} / \mathrm{mL}$ ascorbic acid, and $0.4 \mu \mathrm{M}$ monothioglycerol) in ultralow attachment plates. After $24 \mathrm{~h}$, the media were replaced with endoderm induction media (10 $\mu \mathrm{M}$ Y-27632, $0.5 \mathrm{ng} / \mathrm{mL}$ BMP4, $2.5 \mathrm{ng} / \mathrm{mL}$ FGF2, and $100 \mathrm{ng} / \mathrm{mL}$ Activin A in SFD media). Extra media were added every day for 3 days. The embryoid bodies were collected and dissociated using $0.05 \%$ Trypsin/EDTA, and plated on fibronectin-coated plates with a cell density of 85,000 cells $/ \mathrm{cm}^{2}$. Cells were then incubated in anteriorization media-1 (100 ng/mL Noggin, and $10 \mu \mathrm{M}$ SB431542 in SFD media), followed by an incubation with anteriorization media-2 (10 $\mu \mathrm{M}$ SB431542, and $1 \mu \mathrm{M}$ IWP2 in SFD media). The anteriorization media- 2 were replaced with ventralization media (3 $\mu$ M CHIR99021, $10 \mathrm{ng} / \mathrm{mL}$ FGF10, $10 \mathrm{ng} / \mathrm{mL}$ FGF7, $10 \mathrm{ng} / \mathrm{mL}$ BMP4, and $50 \mathrm{nM}$ alltrans retinoic acid in SFD media), and incubated for two days. The cell monolayer was then lifted by gentle pipetting, and the suspended cells were transferred to an ultralow attachment plate where they would form the lung organoids.

\subsection{Drug Testing and Drug-Sensitivity Quantification}

Approximately $4 \times 10^{4}$ Vero-E6 or Calu-3 cells were seeded per well in 96-well plates. The cells were grown for $24 \mathrm{~h}$ in DMEM or DMEM-F12, respectively, supplemented with $10 \%$ FBS and Pen-Strep. The medium was then replaced with DMEM or DMEM-F12 containing $0.2 \%$ BSA, Pen-Strep, and the compounds in 3-fold dilutions at 7 different concentrations. No compounds were added to the control wells. The cells were infected with SARS-CoV-2 or SARS-CoV-2-mCherry strains at an moi of 0.01 or mock. After $48 \mathrm{~h}$ of infection, drug efficacy on SARS-CoV-2-mCherry infected cells was measured on PFA- or acetone-fixed cells with fluorescence, as described previously [36]. After $72 \mathrm{~h}$ of infection, a CellTiter-Glo (CTG, Promega, Madison, WI, USA) and CellTox Green (CTxG, Promega) 
assays were performed to measure cell viability and cytotoxicity, respectively, as described previously [36-38].

For testing compound toxicity and efficacy against FluAV, approximately $4 \times 10^{4}$ A549 cells were seeded in each well of a 96-well plate. The cells were grown for $24 \mathrm{~h}$ in DMEM, supplemented with 10\% FBS and Pen-Strep. The medium was then replaced with DMEM containing 0.2\% BSA, Pen-Strep, $0.5 \mu \mathrm{g} / \mathrm{mL}$ TPSK-trypsin, and compounds in three-fold dilutions at seven different concentrations. No compounds were added to the control wells. The cells were infected with FluAV (moi $=0.5)$ or mock. At $48 \mathrm{hpi}$, the medium was removed, and a CTG assay was performed to measure cell viability.

For testing compound toxicity and efficacy against HIV-1, approximately $4 \times 10^{4}$ TZM-bl cells were seeded in each well of a 96-well plate in DMEM, supplemented with 10\% FBS and Pen-Strep. The cells were grown for $24 \mathrm{~h}$ in a growth medium. The medium was then replaced with DMEM containing 0.2\% BSA, Pen-Strep, and the compounds in 3-fold dilutions at 7 different concentrations. No compounds were added to the control wells. The cells were infected with HIV-1 (corresponding to $300 \mathrm{ng} / \mathrm{mL}$ of HIV-1 p24) or mock. At $48 \mathrm{~h}$ post-infection (hpi), the medium was removed from the cells, the cells were lysed, and firefly luciferase activity was measured using the Luciferase Assay System (Promega, Madison, WI, USA). In a parallel experiment, a CTG assay was performed to measure cell viability.

We also examined cytotoxicity and antiviral activity of drug combinations, using GFP-expressing HCV in Huh-7.5 cells by following previously described procedures [39].

For testing compound toxicity and efficacy against HEV, electroporated Huh-7.5 cells were seeded in the 384-well plate $\left(3 \times 10^{3}\right.$ cells/well) with immune-modulators at indicated concentrations for $72 \mathrm{~h}$. HEV replication was analyzed by determining the number of GFP-positive cells, using fully automated confocal microscopy (Operetta CLS; PerkinElmer Devices, Waltham, MA, USA).

The half-maximal cytotoxic concentration $\left(\mathrm{CC}_{50}\right)$ for each compound was calculated based on viability/death curves obtained on mock-infected cells, after non-linear regression analysis with a variable slope using GraphPad Prism software version 7.0a. The halfmaximal effective concentrations $\left(\mathrm{EC}_{50}\right)$ were calculated based on the analysis of the viability of infected cells by fitting drug dose-response curves using a four-parameter ( $4 P L)$ logistic function $f(x)$ :

$$
f(x)=A_{\min }+\frac{A_{\max }-A_{\min }}{1+\left(\frac{x}{m}\right)^{\lambda}}
$$

where $f(x)$ is a response value at dose $x, A_{\min }$ and $A_{\max }$ are the upper and lower asymptotes (minimal and maximal drug effects), $m$ is the dose that produces the half-maximal effect $\left(\mathrm{EC}_{50}\right.$ or $\mathrm{CC}_{50}$ ), and $\lambda$ is the steepness (slope) of the curve. The relative effectiveness of the drug was defined as the selectivity index $\left(S I=C_{50} / \mathrm{EC}_{50}\right)$.

To quantify each drug response in a single metric, a drug sensitivity score (DSS) was calculated as a normalized version of the standard area under dose-response curve (AUC), with the baseline noise subtracted, and the normalized maximal response at the highest concentration (often corresponding to off-target toxicity):

$$
D S S=\frac{A U C-t\left(x_{\max }-x_{\min }\right)}{(100-t)\left(x_{\max }-x_{\min }\right) \log _{10} A \min }
$$

where activity threshold $t$ equals $10 \%$, and DSS is in the $0-50$ range [40,41].

\subsection{Drug Combination Testing and Synergy Calculations}

Calu-3, A549, TZM-bl, or Huh-7.5 cells were treated with different concentrations of two drugs and infected with SARS-CoV-2-mCherry (moi $=0.01$ ), FluAV (moi $=0.5)$, HIV-1 (corresponding to $300 \mathrm{ng} / \mathrm{mL}$ of HIV-1 p24), HCV, or mock. In addition, HEV-expressing Huh-7.5 cells were treated with different concentrations of two drugs. After $48 \mathrm{~h}$, cell 
viability and reporter protein expression (SARS-CoV-2-mCherry, HIV-1, HCV-GFP, and HEV-GFP) were measured.

To test whether the drug combinations acted synergistically, the observed responses were compared with expected combination responses. The expected responses were calculated based on the ZIP reference model, using SynergyFinder version 2 [42,43]. Final synergy scores were quantified as average excess response due to drug interactions (i.e., $10 \%$ of cell survival beyond the expected additivity between single drugs represents a synergy score of 10). Additionally, we calculated most synergistic area scores for each drug combination - the most synergistic 3-by-3 dose-window in dose-response matrices.

LOs were treated with $0.5 \mu \mathrm{M}$ remdesivir, $5 \mathrm{ng} / \mathrm{mL}$ IFN $\alpha 2 \mathrm{a}$, or their combination, and infected with SARS-CoV-2-mCherry (moi $=0.1)$. No compounds were added to the control wells. At $72 \mathrm{hpi}$, the LOs were stained using CTxG, and cell nuclei were stained with DAPI. Cells were fixed with PFA and imaged using an EVOS fluorescence microscope. Representative images $(n=3)$ were selected.

\subsection{Gene Expression Analysis}

Calu-3 cells or LOs were treated with drugs or vehicles, and infected with SARS-CoV2-mCherry or mock. Total RNA was isolated using an RNeasy Plus Mini Kit (Qiagen, Hilden, Germany) from Calu-3 cells, or LOs. Polyadenylated mRNA was isolated from $250 \mathrm{ng}$ of total RNA with a NEBNext Poly(A) mRNA Magnetic Isolation Module. A NEBNext Ultra II Directional RNA Library Prep Kit from Illumina was used to prepare samples for sequencing. Sequencing was done on a NextSeq 500 instrument (set up: single-end $1 \times 76 \mathrm{bp}+$ dual index 8 bp) using a NextSeq High Output 75-cycle sequencing kit (up to $400 \mathrm{M}$ reads per flow cell). Reads were aligned using the Bowtie 2 software package version 2.4.2 to the NCBI reference sequence for SARS-CoV-2 (NC_045512.2) and to the Mesocricetus auratus MesAur1.0 assembly genome (https:/ / ftp.ensembl.org/pub/release100/fasta/mesocricetus_auratus/dna/, accessed on 1 May 2021). The number of mapped and unmapped reads that aligned to each gene were obtained with the featureCounts function from the Rsubread R-package version 2.10. The GTF table for the SARS-CoV-2 reference sequence was downloaded from https:/ / ftp.ncbi.nlm.nih.gov/genomes/all/GCF/009/85 8/895/_009858895.2_SM985889v3/GCF_009858895.2_ASM985889v3_genomic.gtf.gz (accessed on 1 May 2021). The heatmaps were generated using the pheatmap package (https:/ / cran.r-project.org/web/packages/pheatmap/index.html, accessed on 1 May 2021), based on log2-transformed or non-transformed profiling data. The clustered heatmaps were produced with the pheatmap v 1.0.12 R package, using either euclidean or minkowski distance functions (Raivo Kolde (2019). pheatmap: Pretty Heatmaps. R package version 1.0.12. https:/ / cran.r-project.org/package=pheatmap, accessed on 1 May 2021).

\subsection{Metabolic Analysis}

Calu-3 cells or LOs were treated with drugs or vehicle, and infected with SARS-CoV2-mCherry or mock. Metabolites were extracted from Calu-3 cells and LO supernatants, and analyzed as described [44]. The heatmaps were generated using the pheatmap package (https:/ / cran.r-project.org/web / packages/pheatmap/index.html, accessed on 1 May 2021), based on log2-transformed or non-transformed profiling data. The clustered heatmaps were produced with the pheatmap v 1.0.12 R package, using either euclidean or minkowski distance functions (Raivo Kolde (2019). pheatmap: Pretty Heatmaps. R package version 1.0.12. https:/ / cran.r-project.org/package=pheatmap, accessed on 1 May 2021).

\section{Results}

3.1. Type I IFNs Reduce SARS-CoV-2 Replication More Efficiently Than Type II and III IFNs in Cell Cultures

Although dexamethasone has been shown to improve survival of patients with severe or critical COVID-19 [45], there are currently no curative therapies against SARS-CoV2. However, previous studies have uncovered several potent antiviral agents, including 
IFNs, against SARS-CoV-2 in vitro and in vivo $[17,18,30]$. Here, we tested type I, II, and III IFNs against wild-type SARS-CoV-2 (multiplicity of infection (moi) = 0.01) in Calu-3 and Vero-E6 cells, using cell viability and virus plaque reduction assays as readouts. We observed that at non-toxic concentrations, type I IFNs rescued both cell types from virusmediated death, and reduced SARS-CoV-2 replication more efficiently than type II and III IFNs. However, the rescue was only partial, and virus replication was reduced only by 2-3 common logarithms (Figure 1).

a

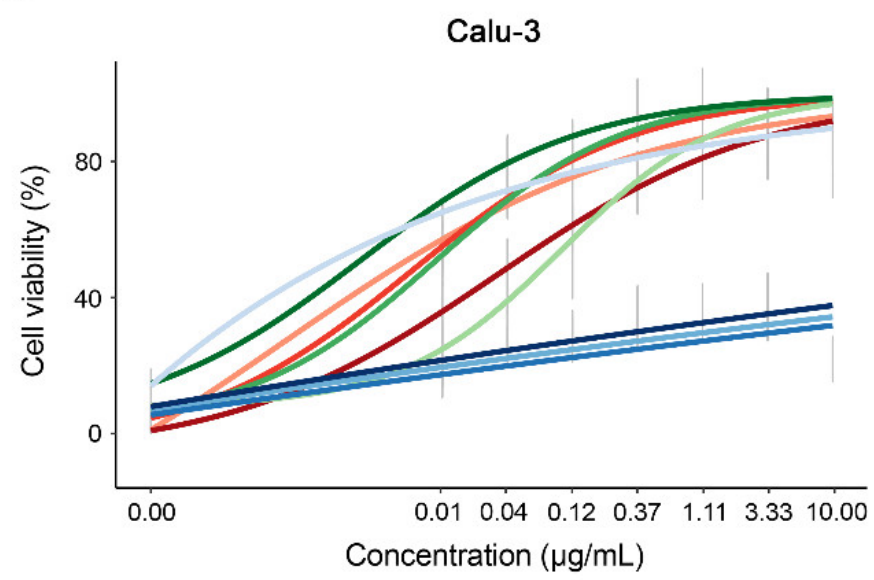

Vero-E6

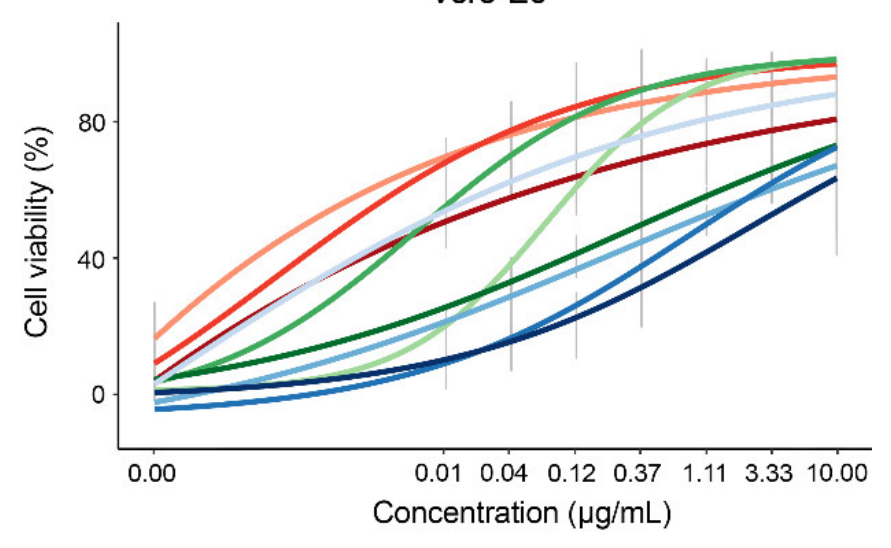

\begin{tabular}{|c|c|c|c|c|c|c|c|c|c|c|c|}
\hline & & & & \multirow{2}{*}{\multicolumn{2}{|c|}{$\begin{array}{c}\text { Type I } \\
\text { IFNs } \\
=\text { IFNA1b }- \text { IFNA }\end{array}$}} & & & \multirow{2}{*}{$\begin{array}{l}\text { - Type II } \\
\text { IFNs } \\
1 \text {-IFNy }\end{array}$} & \multicolumn{2}{|c|}{$\mathcal{C}_{\text {TIFNs }}^{\text {Type III }}$} & \multirow[b]{2}{*}{-IP10 } \\
\hline & & \multicolumn{4}{|c|}{$-I F N B 1 a-I F N B 1 b-I F N A 1 b-I F N A 2 a-I F N A 2 b-I F N W 1$} & & & & $-1 \mathrm{~L} 28 \mathrm{a}$ & $-\mathrm{IL} 29$ & \\
\hline \multirow{2}{*}{ מُ } & Calu-3 & 32.7 & 41.9 & 40.4 & 42.2 & 34.0 & 42.4 & 44.9 & 13.5 & 13.2 & 16.5 \\
\hline & Vero-E6 & 33.8 & 41.9 & 43.0 & 43.8 & 35.3 & 36.7 & 24.1 & 21.9 & 18.0 & 14.5 \\
\hline
\end{tabular}

b
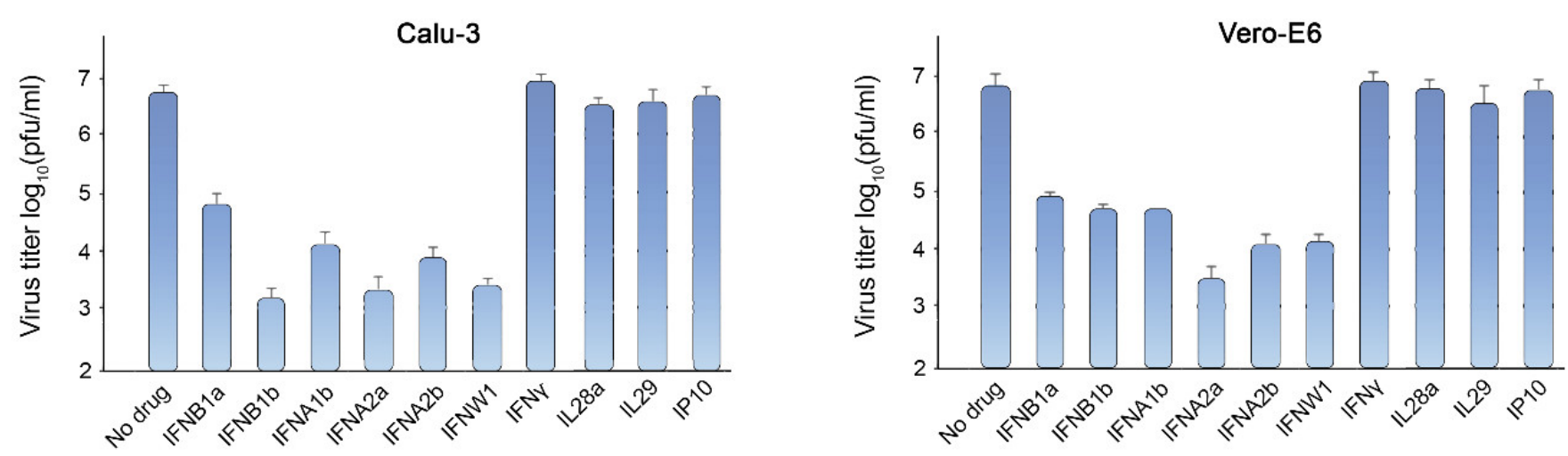

Figure 1. Type I IFNs rescue Calu-3 and Vero-E6 cells from SARS-CoV-2-mediated death and attenuate virus replication. (a) The effect of different doses of IFNs on viability of SARS-CoV-2-infected (moi $=0.01$ ) Calu-3 and Vero-E6 cells. Cell viability was determined using the CTG assay at $72 \mathrm{hpi}$. Mean $\pm \mathrm{SD} ; n=3$. The anti-SARS-CoV-2 activity of the IFNs was quantified using drug sensitivity scores (DSS). (b) The effects of IFNs on viral replication, measured by plaque reduction assay. Mean $\pm \mathrm{SD} ; n=3$. Statistical testing was performed using pairwise Wilcoxon Rank Sum Tests and the results can be found in Table S2.

To identify the type I IFN with the most activity against SARS-CoV-2 infection, we infected IFN-treated and untreated Calu-3 cells with SARS-CoV-2-mCherry (moi $=0.01$ ) and collected media from the cells ( $\mathrm{p} 1$ ) after $48 \mathrm{~h}$. The media were diluted 25-fold and applied to noninfected cells for another $48 \mathrm{~h}$ (p2). Mock-infected cells were used as controls (Figure 2a). Fluorescence microscopy, fluorescence intensity analysis, and cell viability assay of $\mathrm{p} 1$ and $\mathrm{p} 2$ cells showed that IFN $\alpha 1 \mathrm{~b}$, IFN $\alpha 2 \mathrm{a}$, and IFNw 1 were more effective 
inhibitors of SARS-CoV-2 infection than IFNb1a. However, none of the IFNs tested were able to inhibit virus infection completely (Figure $2 \mathrm{~b}-\mathrm{d}$ ).

a

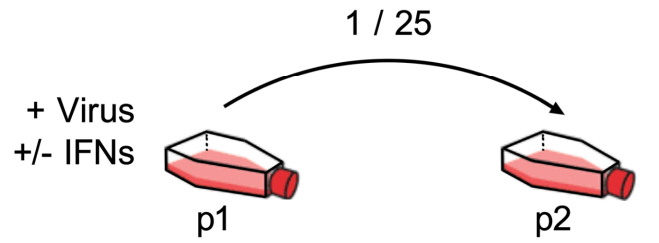

C

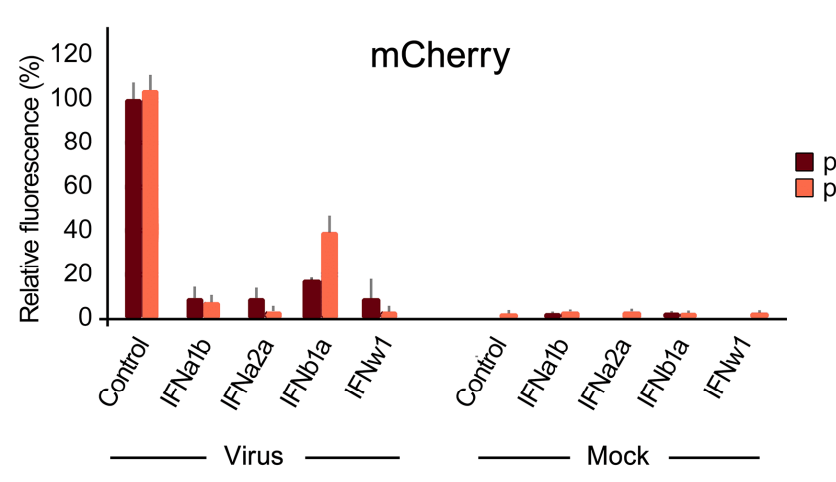

d

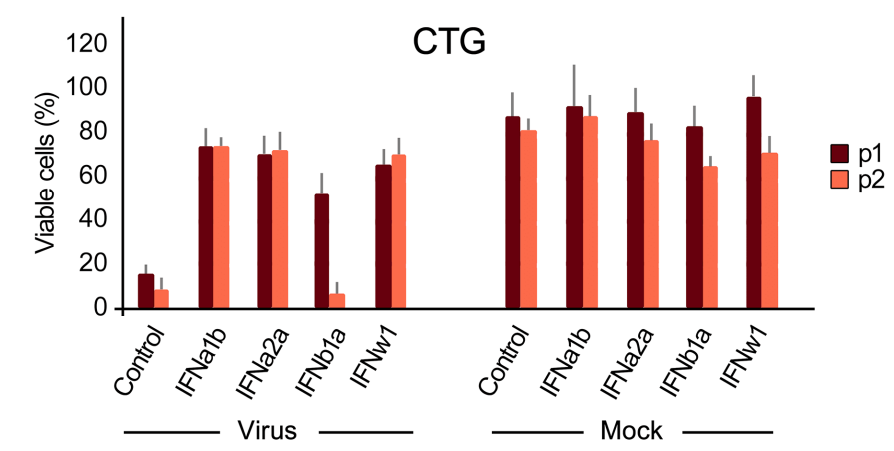

b

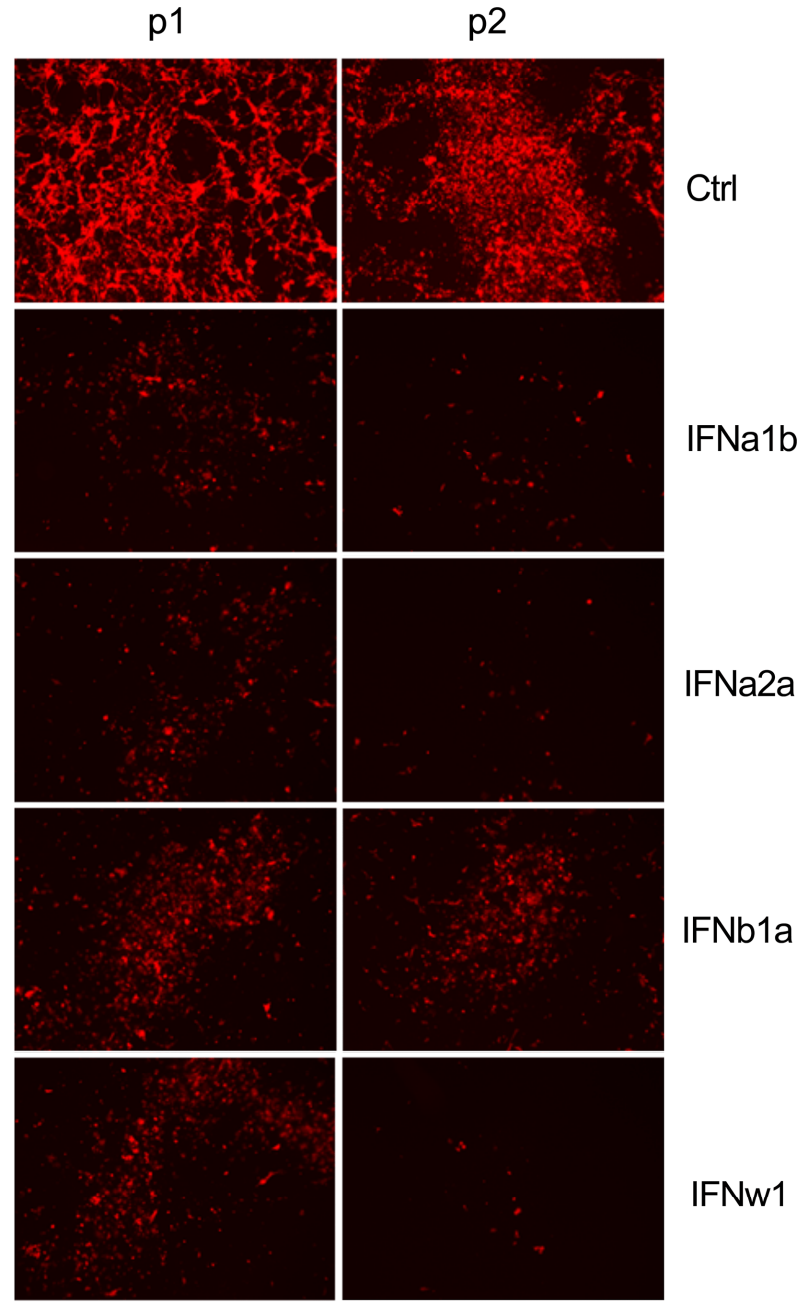

Figure 2. IFN $\alpha 1 b$, IFN $\alpha 2 a$, and IFNw1 are more effective than IFNb1a against SARS-CoV-2-mCherry infection in Calu-3 cells. (a) Schematic representation of the experimental setup. (b) Fluorescent images of non-treated (Ctrl) and IFN-treated $(1 \mu \mathrm{g} / \mathrm{mL})$ SARS-CoV-2-mCherry-infected (moi = 0.01) Calu-3 cells ( $\mathrm{p} 1)$ and cells (p2) treated with 25-fold diluted media from P1 cells taken at 48 hpi. (c,d) Fluorescence intensity and cell viability analyses of p1 and p2 cells at 48 hpi. Mockinfected cells were used as controls (Mean $\pm \mathrm{SD} ; n=3$ ). Statistical testing was performed using pairwise Wilcoxon Rank Sum Tests and the results can be found in Table S3.

Type I IFNs are encoded by multiple genes and vary slightly from one another in their protein structure. In basic research, IFN $\alpha 2 a$ is often used to elucidate the biological activities, structure, and mechanism of action of such type I IFNs. Thus, we next tested IFN $\alpha 2$ a against various doses of SARS-CoV-2-mCherry and different times of drug addition. Calu-3 cells were treated with $1 \mu \mathrm{g} / \mathrm{mL}$ IFN $\alpha 2 \mathrm{a}$ at indicated time points, then infected with SARS-CoV-2-mCherry at the indicated moi. After $48 \mathrm{~h}$, fluorescence intensity and cell viability analyses were performed. We found that the efficacy of IFN $\alpha 2 a$ treatment in preventing SARS-CoV-2 infection was dependent on the viral load, decreasing in efficacy as the moi increased (Figure 3a). We also observed that antiviral efficacy was dependent on the time of addition, with increased efficacy when given prior to infection, rather than following infection (Figure 3b), which is in agreement with previous studies [46,47]. 
a

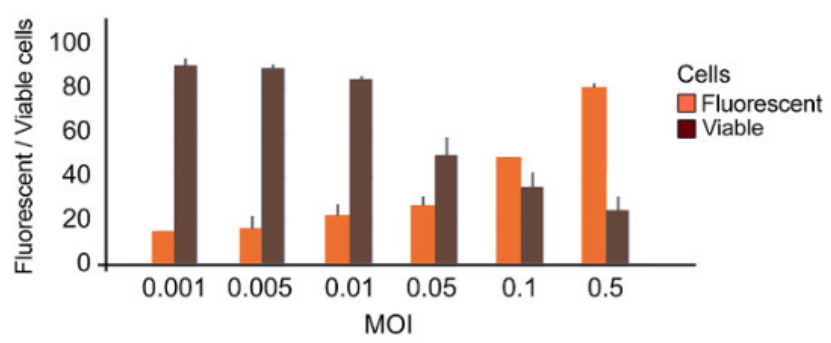

b

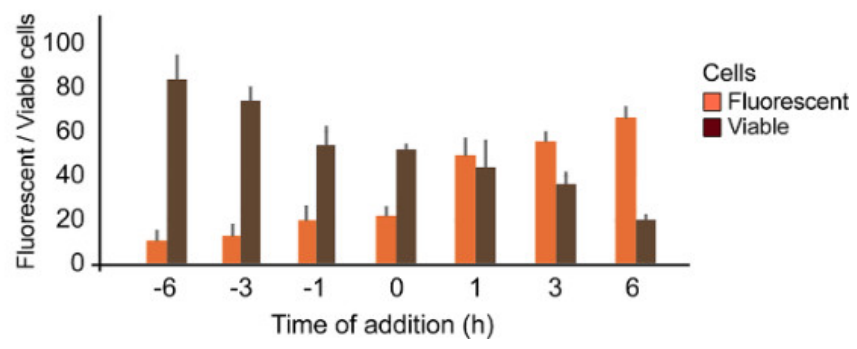

Figure 3. Antiviral activity of IFN $\alpha 2$ a depends on moi of SARS-CoV-2-mCherry and time of drug administration. (a) Calu-3 cells were treated with $1 \mu \mathrm{g} / \mathrm{mL}$ IFN $\alpha 2 \mathrm{a}$ and infected with indicated moi of SARS-CoV-2-mCherry. Fluorescence intensity and cell viability were measured after $48 \mathrm{~h}$ (Mean $\pm \mathrm{SD} ; n=3$ ). (b) Calu-3 cells were treated with $1 \mu \mathrm{g} / \mathrm{mL}$ IFN $\alpha 2 \mathrm{a}$ prior, simultaneously, or post infection with SARS-CoV-2-mCherry $(\mathrm{moi}=0.01)$. Fluorescence intensity and cell viability were measured after $48 \mathrm{~h}$ (Mean $\pm \mathrm{SD} ; n=3$ ).

\subsection{IFN 2 2a Reduces the SARS-CoV-2 RNA Synthesis and Promotes Virus-Mediated Induction of Type III IFNs, IFNb1, and ISGs in Calu-3 Cells}

To shed new light on the mechanism of action of IFN $\alpha 2$ a, we evaluated their effect on expression of cellular and viral RNA in mock- and SARS-CoV-2-infected Calu-3 cells. For this, cells were treated with $1 \mu \mathrm{g} / \mathrm{mL}$ of IFN $\alpha 2 \mathrm{a}$, other type I IFNs, or vehicle; then, they were infected with the virus or mock. After $24 \mathrm{~h}$, we analyzed polyadenylated RNA using RNA-sequencing. We found that IFN $\alpha 2 \mathrm{a}$ and other type I IFNs attenuated production of viral RNA (Figure 4a), while increasing expression of many ISGs in cells, regardless of virusor mock-infection (Figure 4b). These ISGs include IFIT1, IFIT2, and IFIT3, which play a role in recognition of viral RNA; OASL and OAS2, which are involved in RNase L-mediated RNA degradation; and IDO1, which is essential for kynurenine biosynthesis [44,48-50]. Interestingly, IFN $\alpha 2 \mathrm{a}$ and other type I IFNs boosted virus-activated expression of type III IFNs (IFN11, IFN12, IFN13, and IFN14), as well as IFNb1, which is a type I IFN. These results indicate that IFN $\alpha 2$ a does not only trigger expression of ISGs, but also amplifies expression of other IFNs usually activated by viral infections, creating a positive feedback loop of IFN signaling during SARS-CoV-2 infection.

Next, we studied the effect of IFN $\alpha 2$ a on the metabolism of mock- and SARS-CoV2-infected Calu-3 cells. A total of 93 mainly polar metabolites were quantified at 24 hpi (Figure S4). We found that tyrosine and 4-hydroxyproline levels were substantially lowered during viral infection $\left(\log _{2} \mathrm{FC}<-2\right)$. Additionally, administration of IFN $\alpha 2$ a or other type I IFNs lowered the levels of several metabolites, including tryptophan, while increasing kynurenine, regardless of viral infection ( $\log _{2} \mathrm{FC}>3$; Figure $4 \mathrm{c}$ ). This indicates that IFN $\alpha 2 \mathrm{a}$ activates IDO1-mediated kynurenine biosynthesis, which could be associated with adverse reactions, such as suppression of T-cell responses, pain hypersensitivity, and behavior disturbance [51].

\subsection{Synergistic IFN 2 2a-Based Combinations against SARS-CoV-2 Infection in Calu-3 Cells and Lung Organoids}

Next, we examined whether IFN $\alpha 2 a$ in combination with known SARS-CoV-2 inhibitors remdesivir, EIDD-2801, camostat, cycloheximide, or convalescent serum [35-52] can protect cells from virus infection more efficiently and at lower concentrations than IFN $\propto 2$ a alone. Remdesivir and EIDD-2801 are nucleoside analogues, which inhibit viral RNA synthesis [53,54]. Camostat, a serine protease inhibitor, reduces SARS-CoV-2-cell membrane fusion by binding to host TMPRSS2 [55]. In addition, camostat possesses some potential beneficial immunomodulatory effects by interfering with the bradykinin/kallikrein pathways [56]. Cycloheximide inhibits translation elongation and, thereby, reduces SARS$\mathrm{CoV}-2$ replication [57]. Convalescent serum contains neutralizing antibodies that bind to the $S$ protein of SARS-CoV-2, preventing virus entry into the cells [17]. 
a

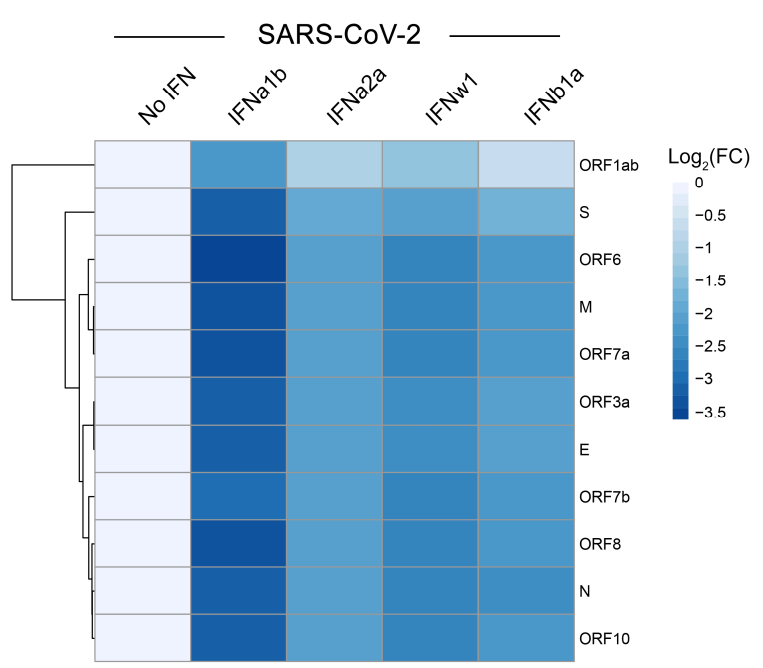

c

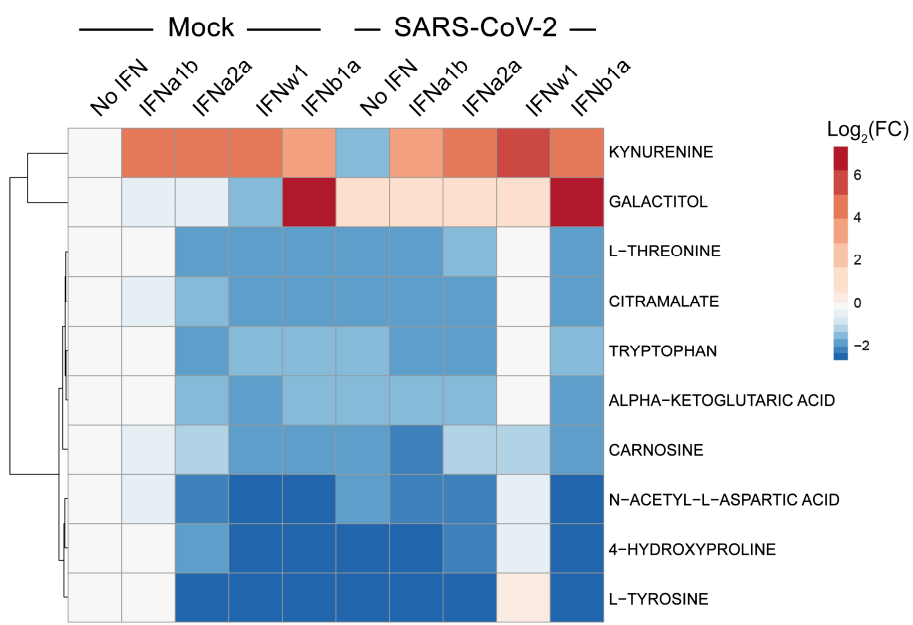

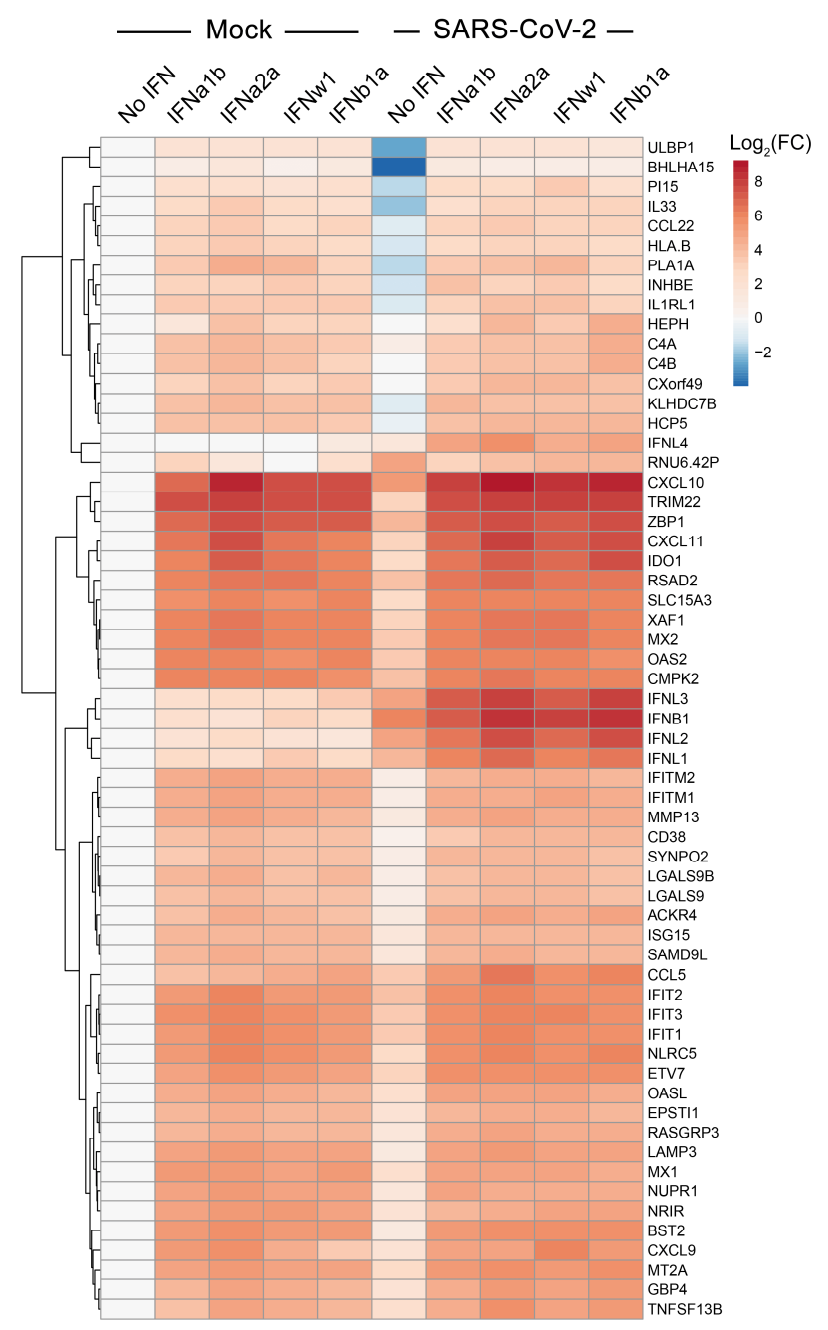

Figure 4. Transcriptomic and metabolomic analyses of mock- and SARS-CoV-2-infected Calu-3 cells, non-treated or treated with type I IFNs. (a) Calu-3 cells were stimulated with IFNs $(1 \mu \mathrm{g} / \mathrm{mL})$ or non-stimulated, and infected with SARS-CoV-2 $(\mathrm{moi}=0.01)$. A heatmap of viral RNAs affected by treatment is shown. Each cell is colored according to the log2-transformed expression values of the samples, expressed as fold-change relative to the non-treated control. (b) Calu-3 cells were either stimulated with recombinant human IFN $(1 \mu \mathrm{g} / \mathrm{mL})$ or left untreated with IFN, then infected with either mock or SARS-CoV-2 (moi = 0.01). A heatmap of the most variable cellular genes affected by treatment and virus infection is shown. Each cell is colored according to the log2-transformed expression values of the samples, expressed as fold-change relative to the non-treated, mock-infected control. (c) Cells were treated as for panel b. After $24 \mathrm{~h}$, the cell culture supernatants were collected, and metabolite levels were determined by LC-MS/MS. A heatmap of the most-affected metabolites is shown. Each cell is colored according to the log2-transformed profiling values of samples, expressed as fold-change relative to the mock control.

We first confirmed the antiviral activities of these known viral inhibitors on Calu-3 cells using SARS-CoV-2-mCherry (Figure 5a and Figure S5a). Then, we tested the antiviral efficacy and toxicity of these agents in combination with IFN $\alpha 2 a$ in Calu-3 cells by monitoring virus-mediated mCherry expression and cell viability (CTG). Each drug combination was tested in a $6 \times 6$ dose-response matrix, where 5 doses of single drugs were combined in a pairwise manner. As a result, we obtained dose-response matrices demonstrating virus inhibition and cell viability achieved by each combination (Figure $5 \mathrm{c}, \mathrm{d}$ and Figure S5b-e). We plotted synergy distribution maps, showing synergy (higher than expected effect) at each pairwise dose. For each drug pair, we calculated average ZIP synergy scores for the whole $6 \times 6$ dose-response matrix and for most synergistic $3 \times 3$ dose-regions, summarizing combination synergies into single metrics (Figure 5e). We 
observed that all combinations showed a strong synergy (synergy scores $>10$ ) at various combination doses. Thus, the observed synergy allowed us to substantially decrease the concentration of both components to achieve antiviral efficacy that was comparable to those of individual drugs at high concentrations.

Both remdesivir and $r h \mathrm{IFN} \alpha 2 \mathrm{a}$ (Pegasys) have been approved for the treatment of COVID-19 infection in several countries. Because of their well-established roles in COVID19 treatment, we decided to further validate the antiviral effect of this combination on iPSC-derived lung organoids (LOs). Thirty-day-old LOs were treated with $5 \mathrm{ng} / \mathrm{mL}$ IFN $\alpha 2 \mathrm{a}, 0.5 \mu \mathrm{M}$ remdesivir, or a combination thereof, then infected with SARS-CoV-2mCherry. At $72 \mathrm{hpi}$, the organoids were analyzed for viral reporter-protein expression

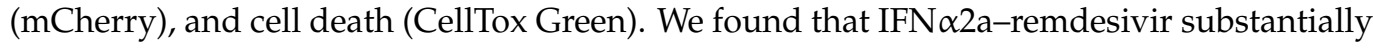
attenuated virus-mediated mCherry expression without affecting cell viability (Figure 6a). Virus titers were determined using plaque reduction assays (Figure 6b). The synergy score for a single dose of the IFN $\alpha 2 a-$-remdesivir combination was 9 (additive/synergistic effect), indicating that IFN $\alpha$-remdesivir was able to attenuate SARS-CoV-2 protein expression and infectious virion production more efficiently than individual agents.

We also evaluated the effect of this combination treatment on viral and cellular RNA expression in LOs. RNA-sequencing revealed that at $48 \mathrm{hpi}$, IFN $\alpha 2 \mathrm{a}-$-remdesivir reduced production of viral RNA to a substantially greater extent, compared to the effect of single agents (Figure 6c). Treatment with IFN $\alpha 2 a$-remdesivir also led to elevated levels of ACE2 and other genes involved in lipid metabolism (APOA4, ADH4, CYP3A7, PON3, FADS6, SDR16C5, ENPP7, FABP2, CUBN, and SERPINA6) [58,59], for which transcription was substantially downregulated during SARS-CoV-2 infection (Figure S6 and Figure 6d). Importantly, the set of IFN $\alpha 2 \mathrm{a}$-induced ISGs in LOs is consistent to what we observed in Calu-3 cells (Figure 66 ).

Furthermore, we studied the effect of IFN $\alpha 2 a$-remdesivir on the metabolism of SARSCoV-2- and mock-infected LOs. A total of 82 metabolites were quantified in LO culture supernatants at $48 \mathrm{hpi}$. Administration of IFN $\alpha 2 \mathrm{a}-$-remdesivir prevented virus-mediated alteration of metabolism, excluding kynurenine biosynthesis (Figure S7 and Figure 6e), which is in line with the results obtained on IFN $\alpha 2 a$-stimulated Calu-3 cells, suggesting that this cocktail has high translatability.

\subsection{Synergistic IFNa2a-Based Combinations against Other Viral Infections In Vitro}

To extend our findings beyond SARS-CoV-2, we tested IFN $\alpha 2$ a in combination with known HCV inhibitors, sofosbuvir and telaprevir, using GFP-expressing HCV in infected Huh-7.5 cells. Sofosbuvir is a nucleoside analogue, which inhibits viral RNA synthesis, whereas telaprevir is an orally available peptidomimetic that targets the HCV serine protease, and disrupts processing of viral proteins and formation of a viral replication complex. Eight different concentrations of the compounds alone or in combination were added to virus- or mock-infected cells. HCV-mediated GFP expression and cell viability were measured after $72 \mathrm{hpi}$ to determine compound efficacy and toxicity. Both IFN $\alpha 2 \mathrm{a}-$ sofosbuvir and IFN $\alpha 2$ a-telaprevir lowered GFP expression without detectable cytotoxicity at indicated concentrations, with synergy scores of 3 and 5 (the most synergistic area scores: 14 and 16), respectively (Figure S8, Table 1). 
a

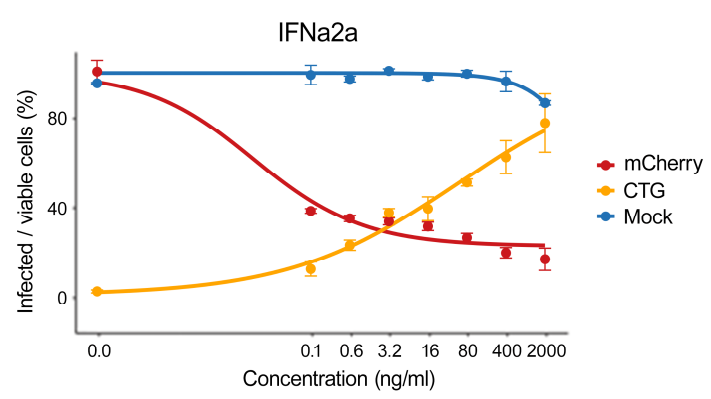

C

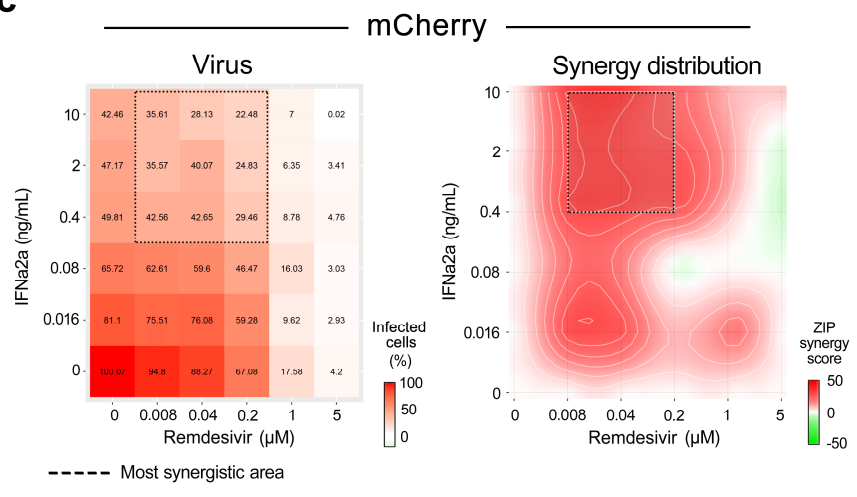

b

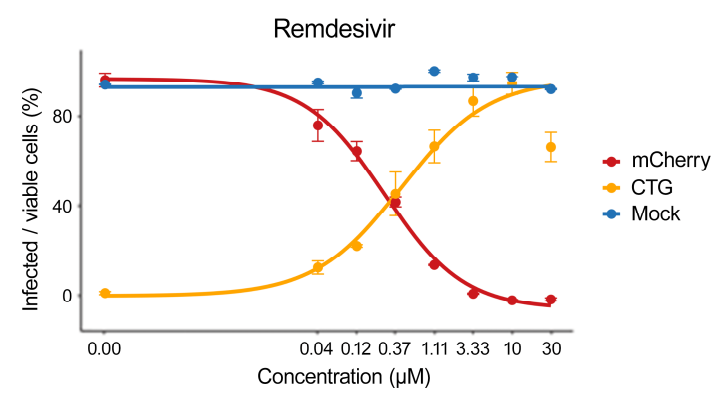

d
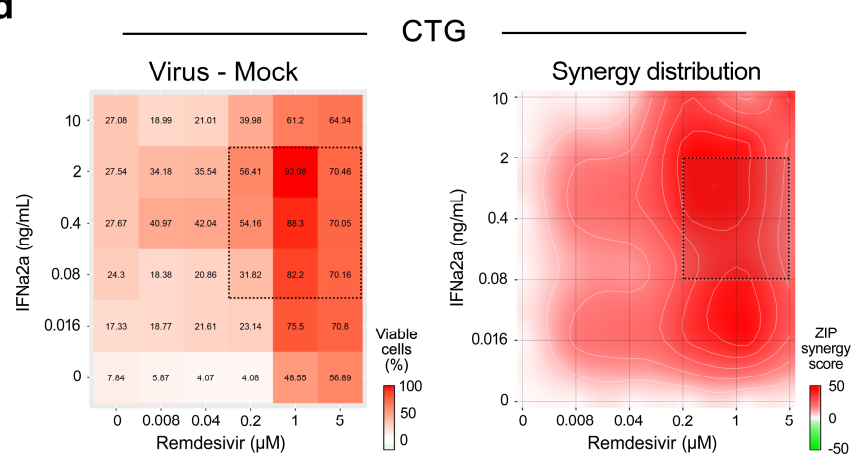

$\mathbf{e}$

\begin{tabular}{|c|c|c|c|c|c|}
\hline & \multicolumn{2}{|c|}{ ZIP synergy score } & \multicolumn{3}{c|}{ Most synergistic area score } \\
\hline IFNa2a plus & mCherry & CTG & mCherry & CTG \\
\hline Camostat & 14.90 & 19.68 & 28.26 & 31.56 \\
\hline Conv. serum & 20.99 & 17.05 & 30.57 & 28.24 \\
\hline EIDD-2801 & 7.94 & 19.43 & 9.16 & 24.48 \\
\hline Cycloheximide & 5.95 & 26.30 & 12.17 & 36.71 \\
\hline Remdesivir & 6.38 & 15.04 & 11.69 & 20.67 \\
\hline
\end{tabular}

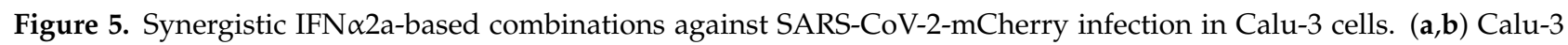
cells were treated with increasing concentrations of IFN $\alpha 2$ a or remdesivir, and infected with the SARS-CoV-2-mCherry or mock. After $48 \mathrm{~h}$, the virus-mediated mCherry expression was measured (red curves). After $72 \mathrm{~h}$, viability of virus- and mock-infected cells was determined using a CTG assay (yellow and blue curves, respectively). Mean \pm SD; $n=3$. (c) The $6 \times 6$ dose-response matrices and interaction landscapes of IFN $\alpha 2$ a and remdesivir obtained using fluorescence analysis of SARS-CoV-2-mCherry-infected Calu-3 cells. ZIP synergy score was calculated for the drug combinations. (d) The $6 \times 6$ dose-response matrices and interaction landscapes of IFN $\alpha 2$ a and remdesivir obtained using a cell viability assay (CTG) on mock- and SARS-CoV-2-mCherry-infected Calu-3 cells. The selectivity for the indicated drug concentrations was calculated (selectivity = efficacy-(100-Toxicity)). ZIP synergy scores were calculated for indicated drug combinations. (e) ZIP synergy scores (synergy score for whole $6 \times 6$ dose-response matrix) and the most synergistic area scores (synergy score for most synergistic $3 \times 3$ dose-regions) calculated for indicated drug combinations.

Next, we studied IFN $\alpha 2 a$ in combination with known HEV inhibitors, NITD008 and ribavirin, against HEV infection in Huh-7.5 cells (Figure S9 and Table 1). Both NITD008 and ribavirin are nucleoside analogs, which inhibit viral RNA synthesis. We observed that IFN $\alpha 2 \mathrm{a}-\mathrm{NITD} 008$ and IFN $\alpha 2 \mathrm{a}$-ribavirin were synergistic against HEV infection (ZIP synergy scores: 11 and 8; the most synergistic area scores: 14 and 19, respectively), while remaining nontoxic at synergistic doses for either drug. 
a
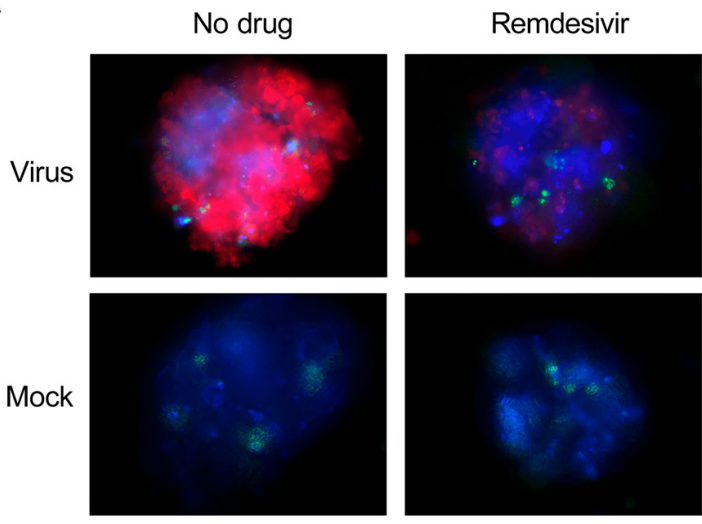
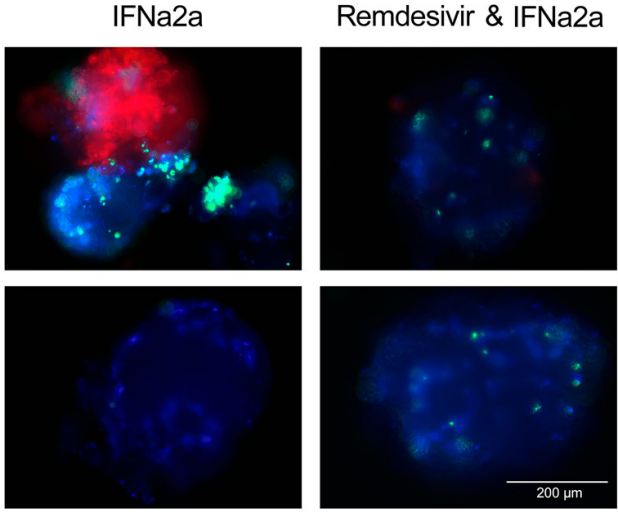

SARS-CoV-2-mCherry

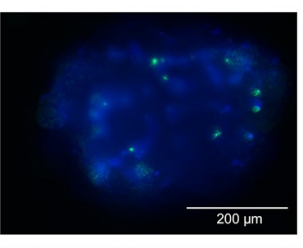

CTxG $\square$ DAPI b

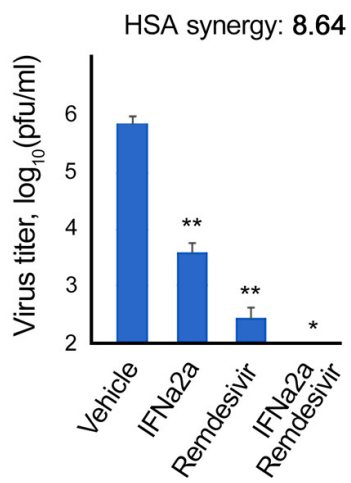

C SARS-CoV2-mCherry

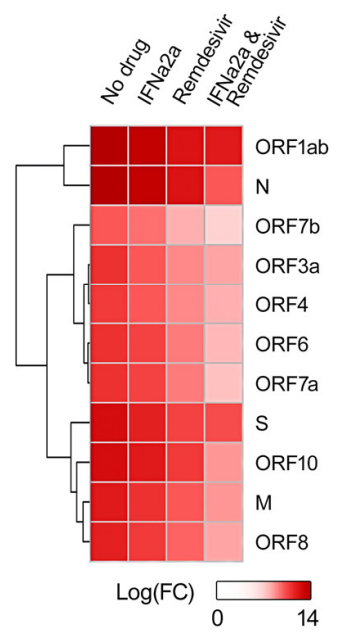

d

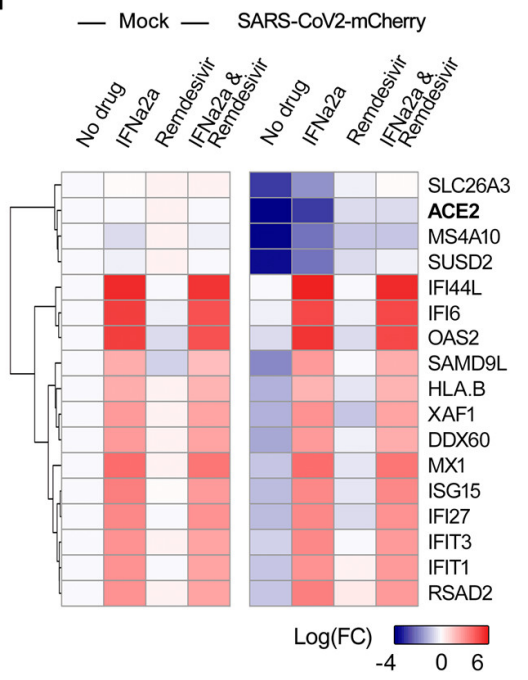

e

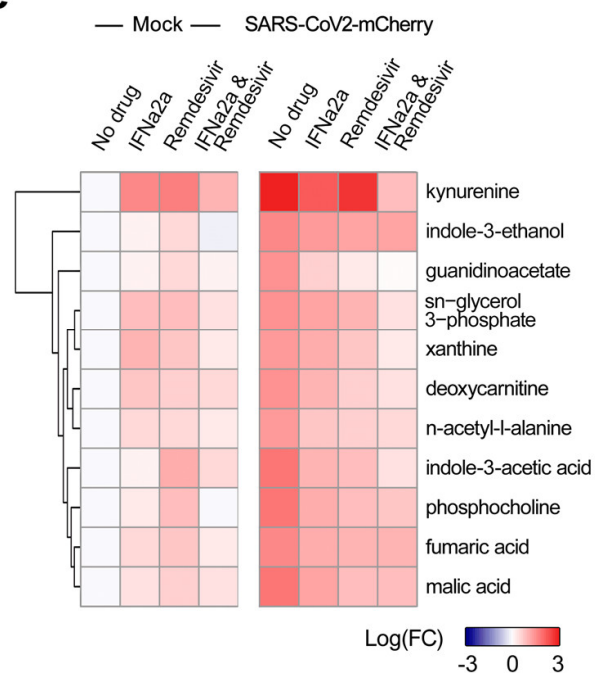

Figure 6. Antiviral effect of IFN $\alpha 2 a-$ remdesivir combination in human lung organoids (LOs). (a) LOs were treated with $0.5 \mu \mathrm{M}$ remdesivir, $5 \mathrm{ng} / \mathrm{mL}$ IFN $\alpha 2 \mathrm{a}$, their combination, or vehicle, and infected with SARS-CoV-2-mCherry $(\mathrm{moi}=0.1)$ or mock. Fluorescence of drug- or carrier-treated SARS-CoV-2-mCherry-infected LOs was detected at 72 hpi. Virus infection, cell nuclei, and cytotoxicity are shown in red, blue, and green, respectively. Scale bars, $200 \mu \mathrm{m}$. (b) The effects of IFN $\alpha-$ remdesivir combination on viral replication in LOs, measured by plaque reduction assay. Mean $\pm \mathrm{SD} ; n=3$. Statistical significance is indicated with asterisks $\left({ }^{*} p<0.05,{ }^{* *} p<0.1\right.$, Wilcoxon test), the significance levels were compared to the vehicle. Synergy score for single dose of IFN $\alpha$-remdesivir combination was calculated as an excess combinatorial effect over expected effect, given by the HSA synergy model. (c) LOs were treated with $0.5 \mu \mathrm{M}$ remdesivir, $5 \mathrm{ng} / \mathrm{mL}$ IFN $\alpha 2 \mathrm{a}$, their combination, or vehicle, and infected with SARS-CoV-2-mCherry (moi $=0.1$ ). After $48 \mathrm{~h}$, total RNA was extracted and sequenced. A heatmap of viral RNAs affected by treatment is shown. Each cell is colored according to the log2-transformed expression values of the samples, expressed as $\log 2$ fold-change relative to the non-treated control. (d) LOs were treated and infected as for panel a. After $48 \mathrm{~h}$, total RNA was extracted and sequenced. A heatmap of the most variable cellular genes affected by treatment and virus infection is shown. Each cell is colored according to the log2-transformed expression values of the samples, expressed as fold-change relative to the non-treated, mock-infected control. Cut-off-3.75. (e) Cells were treated as for panel a. After $48 \mathrm{~h}$, the cell culture supernatants were collected, and metabolite levels were determined by LC-MS/MS. A heatmap of the most-affected metabolites is shown. Each cell is colored according to the log2-transformed profiling values of samples, expressed as fold-change relative to the mock control. Cut-off-1.5. 
Table 1. Synergy and the most synergistic area scores of IFN $\alpha 2 a$-based combinations tested against $\mathrm{HCV}, \mathrm{HEV}$, FluAV, and HIV infections in cell cultures.

\begin{tabular}{ccccc}
\hline Virus & Cell Line & IFN $\alpha$ 2a Plus & ZIP Synergy Score & Most Synergistic Area Score \\
\hline HCV & Huh-7.5 & Sofosbuvir & 3.2 & 13.7 \\
\hline & & Telaprevir & 5.0 & 15.7 \\
\hline HEV & Huh-7.5 & NITDD008 & 7.8 & 18.7 \\
\hline FluAV & A549 & Ribavirin & 10.7 & 14.4 \\
\hline HIV & TZM-bl & Lamivudine & 5.7 & 42.8 \\
\hline
\end{tabular}

We also tested IFN $\alpha 2 a$ in combination with known influenza inhibitor pimodivir against FluAV infection in A549 cells. Pimodivir (VX-787, JNJ-63623872) is an orally available anti-FluAV agent that targets viral polymerase basic protein 2, inhibits capsnatching, and has shown promising results in Phase II clinical trials [60,61]. Cell viability was measured after $48 \mathrm{~h}$ in FluAV-and mock-infected cells to determine efficiency and toxicity of each compound and their combinations with IFN $\alpha 2 a$ (Figure S10 and Table 1). We observed that IFN $\alpha 2 a$-pimodivir was synergistic against FluAV infection (ZIP synergy score: 22 , the most synergistic area score: 43 ), while remaining nontoxic at synergistic doses for either drug.

Finally, we tested IFN $\alpha 2 a$ in combination with known antiretroviral agent lamivudine against HIV-1 in TZM-bl cells. Lamivudine (3TC) is an orally available anti-HIV drug that inhibits viral reverse transcriptase [62]. Cell viability and HIV-induced luciferase expression were measured for each compound or their combination with IFN $\alpha 2 a$ after $48 \mathrm{~h}$. We identified that treatment with IFN $\alpha 2 \mathrm{a}$ and lamivudine was effective, while being nontoxic at synergistic drug concentrations, with ZIP synergy scores of 6 and a ZIP synergy score at the most synergistic area of 11 (Figure S11 and Table 1).

\section{Discussion}

Currently, combinational therapies are still largely eschewed for the treatment of emerging viral infections in favor of monotherapies. This is in part due to the fact that many drug-drug interactions have not been fully explored or understood [63]. Here, we have reported several synergistic IFN $\alpha$-based combination therapies that have better efficacy and lower toxicity than single drugs in vitro. We reported activities of IFN $\alpha 2$ a combinations with remdesivir, EIDD-2801, camostat, cycloheximide, and convalescent serum against SARS-CoV-2. We also identified synergistic activity of IFN $\alpha 2 a$ with sofosbuvir or telaprevir against HCV infection, NITD008 or ribavirin against HEV infection, pimodivir against FluAV, as well as lamivudine against HIV-1 infection.

Based on our experiments, we propose the following mechanism of synergistic action for IFN $\alpha$-based combinations (Figure 7). IFN $\alpha$ induces transcription of IFIT1, IFIT2, and IFIT3, as well as of OASL and OAS2, which recognize viral RNA and catalyze RNase L-mediated RNA degradation, respectively. Remdesivir, EIDD-2801, NITD008, ribavirin, sofosbuvir, pimodivir, and lamivudine, also inhibit viral RNA transcription [53,54,60,64]. Therefore, these antiviral agents and IFN $\alpha$ target the same step of viral replication to achieve synergy. Similarly, other IFN $\alpha$-induced ISGs, together with inhibitors, can synergistically target the same processes, which play a critical role in viral replication. This is in agreement with previous studies [65-67].

Interestingly, it has been noted that some patients with severe symptoms can develop autoantibodies targeting their own IFNs, presenting a subset of patients for whom rhIFNs may be beneficial $[68,69]$. Therefore, the administration of IFN-based combinations may not only act as a potent antiviral treatment regimen, but may also actively counteract an immune-evading mechanism used by viruses and boost host immunity. 


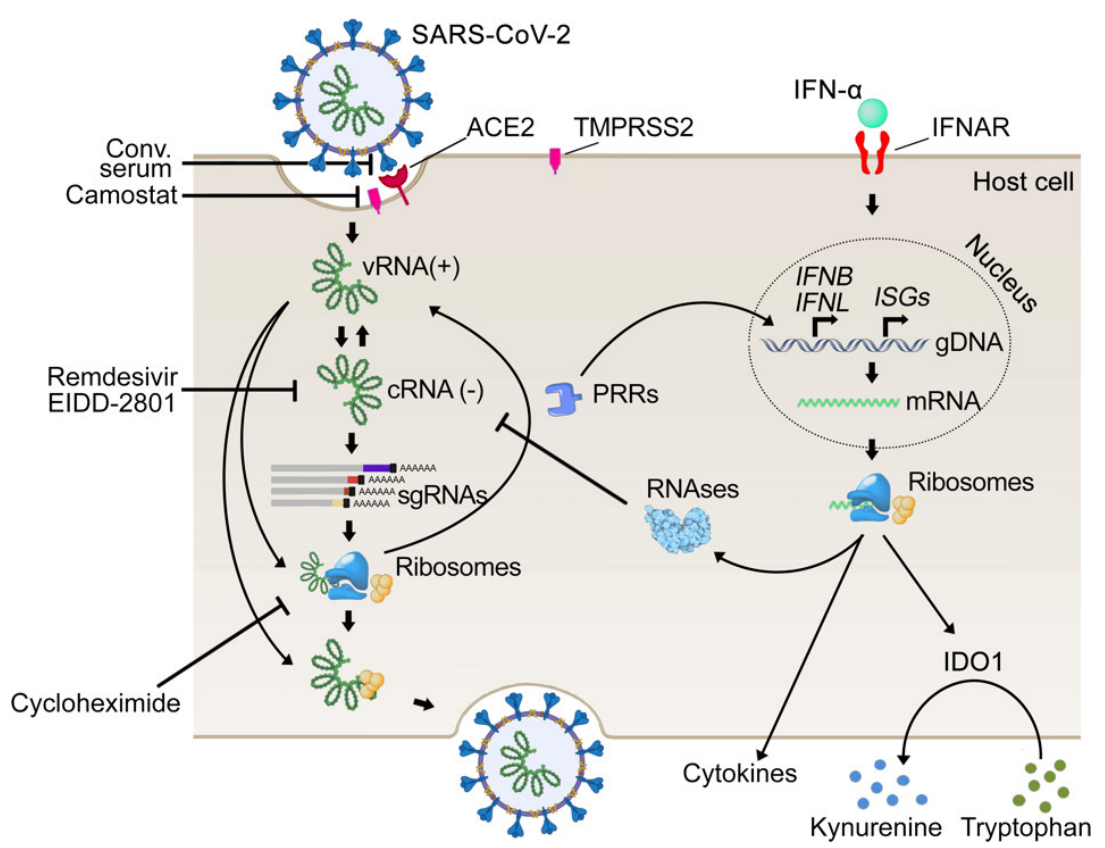

Figure 7. Schematic representation of mechanisms of anti-SARS-CoV-2 actions of remdesivir, EIDD-2801, camostat, cycloheximide, and convalescent serum, and stages of virus replication cycle they target.

It is important to note that for further in vivo studies, it will be necessary to consider the time and route of administration, as well as the metabolism of IFN $\alpha$-containing drug combinations. In particular, intranasal IFN $\alpha$ treatment is beneficial only when administered before the onset of clinical signs in the SARS-CoV-2 hamster model [70]. In addition, earlier intramuscular administration of IFN- $\alpha$ was suggested to be beneficial for COVID-19 patients (10.2217/fvl-2020-0404). Moreover, differences in biological activity and structure between different type I IFNs may reduce the transcription of ISGs, and eliminate the synergistic effect of the combinational treatment [71]. Therefore, the overall antiviral effect for treatment with IFNs in vivo could be dampened. Further studies will be required to determine if the full synergism with IFN $\alpha$-based combinations that was witnessed for in vitro models could be translated in vivo. Despite these difficulties, we believe the identification of this combinational therapy illustrates an important approach to the development of effective antiviral treatment options.

\section{Conclusions}

Our proposed IFN $\alpha$-based drug combinations leverage an approach that balances the bolstering of innate antiviral immunity of the host and supplemental external antiviral activity through the administration of synergistic antiviral agents. Furthermore, combinational antiviral treatments, which reduce viral replication at lower concentrations than are required with monotherapies, are valuable due to their lowered potential for adverse effects and improved outcomes.

Supplementary Materials: The following are available online at https: / www.mdpi.com/article/ 10.3390/v13122489/s1, Table S1: Compounds, their suppliers, and catalogue numbers, Table S2: Statistical analysis of data presented in Figure 1 using pairwise Wilcoxon Rank Sum Test with continuity correction, Table S3: Statistical analysis of data presented in Figure 2 using pairwise Wilcoxon Rank Sum Test, Figure S1: Three types of IFNs and their targets, Figure S2: Developmental statuses of several natural and recombinant human IFNs against a range of pathogenic human viruses, Figure S3: Examples of IFN-based combinations and their developmental statuses, Figure S4: Metabolomic profiles of mock- and SARS-CoV-2-infected Calu-3 cells non-treated or treated with type I IFNs, Figure S5: Synergistic IFNa2a-based combinations against SARS-CoV-2-mCherry infection in 
Calu-3 cells, Figure S6: Effect of IFNa2a-remdesivir on transcription of host genes in human lung organoids (LOs), Figure S7: Effect of IFNa2a-remdesivir on metabolism in human lung organoids (LOs), Figure S8: Combinations of IFNa2a with sofosbuvir or telaprevir reduce HCV-mediated GFP expression in Huh-7.5 cells, Figure S9: Combinations of IFNa2a with ribavirin or NITD008 reduce HEV-mediated GFP expression in Huh-7.5 cells, Figure S10: Combination of pimodivir-IFNa2a reduces FluAV infection in A549 cells, Figure S11: Combination of lamivudine-IFNa2a reduces HIV-1 virus infections in TZM-bl cells.

Author Contributions: Conceptualization, D.E.K.; methodology, A.I., R.Y., E.Z., L.S.L., S.W., E.J., J.Y., E.R., W.W., H.L., K.L., V.O., T.T., M.P.W., M.M.P., A.I.N., S.A.N., M.H.F., G.G., P.A., M.T., A.K., E.L., A.V., N.L., A.M., M.B., D.E.K.; software, A.I.; validation, D.E.K., E.Z., J.Y., E.R., N.L. and E.J.; formal analysis, D.E.K. and A.I.; investigation, D.E.K., A.I. and R.Y.; resources, D.E.K., M.B., L.S.L., S.W., E.J., J.Y., E.R., W.W., K.L., H.L., V.O., T.T., M.P.W., M.M.P., A.I.N., M.H.F., S.A.N., N.L. and G.G.; data curation, D.E.K. and A.I.; writing-original draft preparation, D.E.K. and R.Y.; writing—review and editing, all authors.; visualization, A.I.; supervision, D.E.K., M.P.W., A.M., and M.B.; project administration, D.E.K.; funding acquisition, D.E.K., M.B., M.P.W. and M.M.P. All authors have read and agreed to the published version of the manuscript.

Funding: This research was funded by the European Regional Development Fund, the Mobilitas Pluss Project grant MOBTT39 National Research Foundation of Korea (NRF) grant funded by the Korean government (NRF-2017M3A9G6068246 and 2020R1A2C2009529) and Academy of Finland (grant number 331627). FIMM metabolomics unit was supported by HiLIFE and Biocenter Finland.

Institutional Review Board Statement: All experiments with viruses were performed in BSL2 and BSL3 laboratories in compliance with the guidelines of the national authorities, and under appropriate ethical and safety approvals. Standard operational procedures were approved by the institutional safety committee.

Informed Consent Statement: Not applicable.

Data Availability Statement: All data generated or analyzed during this study are included in this published article and its Supplementary Materials (Tables S1-S3, Figures S1-S10).

Acknowledgments: We thank Biomedicum Function Genomics Unit (FuGu) for transcriptomics analysis.

Conflicts of Interest: The authors declare no conflict of interest. Nicolas Legrand is affiliated with Oncodesign. The author has no financial interests to declare.

\section{References}

1. Zhang, C.H.; Wang, Y.F.; Liu, X.J.; Lu, J.H.; Qian, C.W.; Wan, Z.Y.; Yan, X.G.; Zheng, H.Y.; Zhang, M.Y.; Xiong, S.; et al. Antiviral activity of cepharanthine against severe acute respiratory syndrome coronavirus in vitro. Chin. Med. J. 2005, 118, 493-496. [PubMed]

2. Vos, T.; Abajobir, A.A.; Abate, K.H.; Abbafati, C.; Abbas, K.M.; Abd-Allah, F.; Abdulkader, R.S.; Abdulle, A.M.; Abebo, T.A.; Abera, S.F.; et al. Global, regional, and national incidence, prevalence, and years lived with disability for 328 diseases and injuries for 195 countries, 1990-2016: A systematic analysis for the Global Burden of Disease Study 2016. Lancet 2017, 390, 1211-1259. [CrossRef]

3. Hay, S.I.; Abajobir, A.A.; Abate, K.H.; Abbafati, C.; Abbas, K.M.; Abd-Allah, F.; Abdulkader, R.S.; Abdulle, A.M.; Abebo, T.A.; Abera, S.F.; et al. Global, regional, and national disability-adjusted life-years (DALYs) for 333 diseases and injuries and healthy life expectancy (HALE) for 195 countries and territories, 1990-2016: A systematic analysis for the Global Burden of Disease Study 2016. Lancet 2017, 390, 1260-1344. [CrossRef]

4. Carty, M.; Guy, C.; Bowie, A.G. Detection of Viral Infections by Innate Immunity. Biochem. Pharmacol. 2021, 183, 114316. [CrossRef] [PubMed]

5. Hoffmann, H.H.; Schneider, W.M.; Rice, C.M. Interferons and viruses: An evolutionary arms race of molecular interactions. Trends Immunol. 2015, 36, 124-138. [CrossRef] [PubMed]

6. Park, A.; Iwasaki, A. Type I and Type III Interferons-Induction, Signaling, Evasion, and Application to Combat COVID-19. Cell Host Microbe 2020, 27, 870-878. [CrossRef]

7. Felgenhauer, U.; Schoen, A.; Gad, H.H.; Hartmann, R.; Schaubmar, A.R.; Failing, K.; Drosten, C.; Weber, F. Inhibition of SARS-CoV-2 by type I and type III interferons. J. Biol. Chem. 2020, 295, 13958-13964. [CrossRef] [PubMed]

8. Nice, T.J.; Robinson, B.A.; Van Winkle, J.A. The Role of Interferon in Persistent Viral Infection: Insights from Murine Norovirus. Trends Microbiol. 2018, 26, 510-524. [CrossRef]

9. Mesev, E.V.; LeDesma, R.A.; Ploss, A. Decoding type I and III interferon signalling during viral infection. Nat. Microbiol. 2019, 4, 914-924. [CrossRef] 
10. Shim, J.M.; Kim, J.; Tenson, T.; Min, J.Y.; Kainov, D.E. Influenza Virus Infection, Interferon Response, Viral Counter-Response, and Apoptosis. Viruses 2017, 9, 223. [CrossRef] [PubMed]

11. Zhang, Q.; Bastard, P.; Liu, Z.; Le Pen, J.; Moncada-Velez, M.; Chen, J.; Ogishi, M.; Sabli, I.K.D.; Hodeib, S.; Korol, C.; et al. Inborn errors of type I IFN immunity in patients with life-threatening COVID-19. Science 2020, 370, eabd4570. [CrossRef]

12. Hadjadj, J.; Yatim, N.; Barnabei, L.; Corneau, A.; Boussier, J.; Smith, N.; Péré, H.; Charbit, B.; Bondet, V.; Chenevier-Gobeaux, C.; et al. Impaired type I interferon activity and inflammatory responses in severe COVID-19 patients. Science 2020, 369, 718-724. [CrossRef] [PubMed]

13. Sancho-Shimizu, V.; Perez de Diego, R.; Jouanguy, E.; Zhang, S.Y.; Casanova, J.L. Inborn errors of anti-viral interferon immunity in humans. Curr. Opin. Virol. 2011, 1, 487-496. [CrossRef] [PubMed]

14. Pairo-Castineira, E.; Clohisey, S.; Klaric, L.; Bretherick, A.D.; Rawlik, K.; Pasko, D.; Walker, S.; Parkinson, N.; Fourman, M.H.; Russell, C.D.; et al. Genetic mechanisms of critical illness in Covid-19. Nature 2020, 21, 70. [CrossRef] [PubMed]

15. Fried, M.W.; Shiffman, M.L.; Reddy, K.R.; Smith, C.; Marinos, G.; Goncales, F.L., Jr.; Haussinger, D.; Diago, M.; Carosi, G.; Dhumeaux, D.; et al. Peginterferon alfa-2a plus ribavirin for chronic hepatitis C virus infection. N. Engl. J. Med. 2002, 347, 975-982. [CrossRef]

16. Trepo, C.; Chan, H.L.; Lok, A. Hepatitis B virus infection. Lancet 2014, 384, 2053-2063. [CrossRef]

17. Lazear, H.M.; Schoggins, J.W.; Diamond, M.S. Shared and Distinct Functions of Type I and Type III Interferons. Immunity 2019, 50, 907-923. [CrossRef] [PubMed]

18. Sallard, E.; Lescure, F.X.; Yazdanpanah, Y.; Mentre, F.; Peiffer-Smadja, N. Type 1 interferons as a potential treatment against COVID-19. Antiviral Res. 2020, 178, 104791. [CrossRef] [PubMed]

19. Sa Ribero, M.; Jouvenet, N.; Dreux, M.; Nisole, S. Interplay between SARS-CoV-2 and the type I interferon response. PLoS Pathog. 2020, 16, e1008737. [CrossRef] [PubMed]

20. Wang, B.; Li, D.; Liu, T.; Wang, H.; Luo, F.; Liu, Y. Subcutaneous injection of IFN alpha-2b for COVID-19: An observational study. BMC Infect. Dis. 2020, 20, 723. [CrossRef]

21. Feld, J.J.; Kandel, C.; Biondi, M.J.; Kozak, R.A.; Zahoor, M.A.; Lemieux, C.; Borgia, S.M.; Boggild, A.K.; Powis, J.; McCready, J.; et al. Peginterferon lambda for the treatment of outpatients with COVID-19: A phase 2, placebo-controlled randomised trial. Lancet Respir. Med. 2021, 9, 498-510. [CrossRef]

22. Pan, H.; Peto, R.; Henao-Restrepo, A.M.; Preziosi, M.P.; Sathiyamoorthy, V.; Abdool Karim, Q.; Alejandria, M.M.; Hernández García, C.; Kieny, M.P.; Malekzadeh, R.; et al. Repurposed Antiviral Drugs for Covid-19—Interim WHO Solidarity Trial Results. N. Engl. J. Med. 2020, 384, 497-511. [CrossRef]

23. Monk, P.D.; Marsden, R.J.; Tear, V.J.; Brookes, J.; Batten, T.N.; Mankowski, M.; Gabbay, F.J.; Davies, D.E.; Holgate, S.T.; Ho, L.P.; et al. Safety and efficacy of inhaled nebulised interferon beta-1a (SNG001) for treatment of SARS-CoV-2 infection: A randomised, double-blind, placebo-controlled, phase 2 trial. Lancet Respir. Med. 2020, 9, 196-206. [CrossRef]

24. Sleijfer, S.; Bannink, M.; Van Gool, A.R.; Kruit, W.H.; Stoter, G. Side effects of interferon-alpha therapy. Pharm World Sci. 2005, 27, 423-431. [CrossRef]

25. Ianevski, A.; Yao, R.; Biza, S.; Zusinaite, E.; Mannik, A.; Kivi, G.; Planken, A.; Kurg, K.; Tombak, E.M.; Ustav, M., Jr.; et al. Identification and Tracking of Antiviral Drug Combinations. Viruses 2020, 12, 1178. [CrossRef] [PubMed]

26. Hung, I.F.; Lung, K.C.; Tso, E.Y.; Liu, R.; Chung, T.W.; Chu, M.Y.; Ng, Y.Y.; Lo, J.; Chan, J.; Tam, A.R.; et al. Triple combination of interferon beta-1b, lopinavir-ritonavir, and ribavirin in the treatment of patients admitted to hospital with COVID-19: An open-label, randomised, phase 2 trial. Lancet 2020, 395, 1695-1704. [CrossRef]

27. Idelsis, E.-M.; Jesus, P.-E.; Yaquelin, D.-R.; Dania, V.-B.; Monica, B.-R.; Lisandra, B.-R.; Jesus, C.-R.; Lisbeth, C.C.; Ernesto, P.-C.; Saily, T.-P.; et al. Effect and safety of combination of interferon alpha-2b and gamma or interferon alpha-2b for negativization of SARS-CoV-2 viral RNA. Preliminary results of a randomized controlled clinical trial. medRxiv 2020. [CrossRef]

28. Zhou, Q.; Chen, V.; Shannon, C.P.; Wei, X.S.; Xiang, X.; Wang, X.; Wang, Z.H.; Tebbutt, S.J.; Kollmann, T.R.; Fish, E.N. Interferon$\alpha 2 b$ Treatment for COVID-19. Front. Immunol 2020, 11, 1061. [CrossRef] [PubMed]

29. Alavi Darazam, I.; Shokouhi, S.; Pourhoseingholi, M.A.; Naghibi Irvani, S.S.; Mokhtari, M.; Shabani, M.; Amirdosara, M.; Torabinavid, P.; Golmohammadi, M.; Hashemi, S.; et al. Role of interferon therapy in severe COVID-19: The COVIFERON randomized controlled trial. Sci. Rep. 2021, 11, 8059. [CrossRef]

30. Ianevski, A.; Yao, R.; Fenstad, M.H.; Biza, S.; Zusinaite, E.; Reisberg, T.; Lysvand, H.; Løseth, K.; Landsem, V.M.; Malmring, J.F.; et al. Potential Antiviral Options against SARS-CoV-2 Infection. Viruses 2020, 12, 642. [CrossRef] [PubMed]

31. Andersen, P.I.; Ianevski, A.; Lysvand, H.; Vitkauskiene, A.; Oksenych, V.; Bjørås, M.; Telling, K.; Lutsar, I.; Dumpis, U.; Irie, Y.; et al. Discovery and development of safe-in-man broad-spectrum antiviral agents. Int. J. Infect. Dis. 2020, 93, 268-276. [CrossRef] [PubMed]

32. Andersen, P.I.; Krpina, K.; Ianevski, A.; Shtaida, N.; Jo, E.; Yang, J.; Koit, S.; Tenson, T.; Hukkanen, V.; Anthonsen, M.W. Novel antiviral activities of obatoclax, emetine, niclosamide, brequinar, and homoharringtonine. Viruses 2019, 11, 964. [CrossRef] [PubMed]

33. Ianevski, A.; Andersen, P.I.; Merits, A.; Bjørås, M.; Kainov, D. Expanding the activity spectrum of antiviral agents. Drug Discov. Today 2019, 24, 1224-1228. [CrossRef]

34. Rihn, S.J.; Merits, A.; Bakshi, S.; Turnbull, M.L.; Wickenhagen, A.; Alexander, A.J.T.; Baillie, C.; Brennan, B.; Brown, F.; Brunker, K.; et al. A plasmid DNA-launched SARS-CoV-2 reverse genetics system and coronavirus toolkit for COVID-19 research. PLoS Biol. 2021, 19, e3001091. [CrossRef] 
35. Ko, M.; Chang, S.Y.; Byun, S.Y.; Ianevski, A.; Choi, I.; Pham Hung d'Alexandry d'Orengiani, A.L.; Ravlo, E.; Wang, W.; Bjoras, M.; Kainov, D.E.; et al. Screening of FDA-Approved Drugs Using a MERS-CoV Clinical Isolate from South Korea Identifies Potential Therapeutic Options for COVID-19. Viruses 2021, 13, 651. [CrossRef] [PubMed]

36. Ianevski, A.; Yao, R.; Lysvand, H.; Grødeland, G.; Legrand, N.; Tenson, T.; Bjørås, M.; Kainov, D.E. Nafamostat-interferon-alpha combination suppresses SARS-CoV-2 infection in vitro and in vivo. bioRxiv 2021. [CrossRef]

37. Ianevski, A.; Kulesskiy, E.; Krpina, K.; Lou, G.; Aman, Y.; Bugai, A.; Aasumets, K.; Akimov, Y.; Bulanova, D.; Gildemann, K.; et al. Chemical, Physical and Biological Triggers of Evolutionary Conserved Bcl-xL-Mediated Apoptosis. Cancers 2020, 12, 1694. [CrossRef] [PubMed]

38. Bulanova, D.; Ianevski, A.; Bugai, A.; Akimov, Y.; Kuivanen, S.; Paavilainen, H.; Kakkola, L.; Nandania, J.; Turunen, L.; Ohman, T.; et al. Antiviral Properties of Chemical Inhibitors of Cellular Anti-Apoptotic Bcl-2 Proteins. Viruses 2017, 9, 271. [CrossRef]

39. Lee, M.; Yang, J.; Jo, E.; Lee, J.Y.; Kim, H.Y.; Bartenschlager, R.; Shin, E.C.; Bae, Y.S.; Windisch, M.P. A Novel Inhibitor IDPP Interferes with Entry and Egress of HCV by Targeting Glycoprotein E1 in a Genotype-Specific Manner. Sci. Rep. 2017, 7, 44676. [CrossRef] [PubMed]

40. Potdar, S.; Ianevski, A.; Mpindi, J.P.; Bychkov, D.; Fiere, C.; Ianevski, P.; Yadav, B.; Wennerberg, K.; Aittokallio, T.; Kallioniemi, O.; et al. Breeze: An integrated quality control and data analysis application for high-throughput drug screening. Bioinformatics 2020, 36, 3602-3604. [CrossRef]

41. Yadav, B.; Pemovska, T.; Szwajda, A.; Kulesskiy, E.; Kontro, M.; Karjalainen, R.; Majumder, M.M.; Malani, D.; Murumagi, A.; Knowles, J.; et al. Quantitative scoring of differential drug sensitivity for individually optimized anticancer therapies. Sci. Rep. 2014, 4, 5193. [CrossRef] [PubMed]

42. Ianevski, A.; He, L.; Aittokallio, T.; Tang, J. SynergyFinder: A web application for analyzing drug combination dose-response matrix data. Bioinformatics 2017, 33, 2413-2415. [CrossRef] [PubMed]

43. Ianevski, A.; Giri, A.K.; Aittokallio, T. SynergyFinder 2.0: Visual analytics of multi-drug combination synergies. Nucleic Acids Res. 2020, 48, W488-W493. [CrossRef] [PubMed]

44. Gaelings, L.; Soderholm, S.; Bugai, A.; Fu, Y.; Nandania, J.; Schepens, B.; Lorey, M.B.; Tynell, J.; Vande Ginste, L.; Le Goffic, R.; et al. Regulation of kynurenine biosynthesis during influenza virus infection. FEBS J. 2017, 284, 222-236. [CrossRef] [PubMed]

45. Horby, P.; Lim, W.S.; Emberson, J.R.; Mafham, M.; Bell, J.L.; Linsell, L.; Staplin, N.; Brightling, C.; Ustianowski, A.; Elmahi, E.; et al. Dexamethasone in Hospitalized Patients with Covid-19_Preliminary Report. N. Engl. J. Med. 2020, 371, 654-666. [CrossRef]

46. Rebendenne, A.; Valadao, A.L.C.; Tauziet, M.; Maarifi, G.; Bonaventure, B.; McKellar, J.; Planes, R.; Nisole, S.; Arnaud-Arnould, M.; Moncorge, O.; et al. SARS-CoV-2 triggers an MDA-5-dependent interferon response which is unable to control replication in lung epithelial cells. J. Virol. 2021, 95, e02415-20. [CrossRef] [PubMed]

47. Mantlo, E.; Bukreyeva, N.; Maruyama, J.; Paessler, S.; Huang, C. Antiviral activities of type I interferons to SARS-CoV-2 infection. Antiviral Res. 2020, 179, 104811. [CrossRef]

48. Pichlmair, A.; Lassnig, C.; Eberle, C.A.; Górna, M.W.; Baumann, C.L.; Burkard, T.R.; Bürckstümmer, T.; Stefanovic, A.; Krieger, S.; Bennett, K.L.; et al. IFIT1 is an antiviral protein that recognizes 5'-triphosphate RNA. Nat. Immunol 2011, 12, 624-630. [CrossRef] [PubMed]

49. Zhou, X.; Michal, J.J.; Zhang, L.; Ding, B.; Lunney, J.K.; Liu, B.; Jiang, Z. Interferon induced IFIT family genes in host antiviral defense. Int. J. Biol. Sci. 2013, 9, 200-208. [CrossRef] [PubMed]

50. Gusho, E.; Baskar, D.; Banerjee, S. New advances in our understanding of the "unique" RNase L in host pathogen interaction and immune signaling. Cytokine 2020, 133, 153847. [CrossRef] [PubMed]

51. Boergeling, Y.; Ludwig, S. Targeting a metabolic pathway to fight the flu. FEBS J. 2017, 284, 218-221. [CrossRef] [PubMed]

52. Ritchie, M.E.; Phipson, B.; Wu, D.; Hu, Y.; Law, C.W.; Shi, W.; Smyth, G.K. limma powers differential expression analyses for RNA-sequencing and microarray studies. Nucleic Acids Res. 2015, 43, e47. [CrossRef]

53. Sheahan, T.P.; Sims, A.C.; Zhou, S.; Graham, R.L.; Pruijssers, A.J.; Agostini, M.L.; Leist, S.R.; Schäfer, A.; Dinnon, K.H., 3rd; Stevens, L.J.; et al. An orally bioavailable broad-spectrum antiviral inhibits SARS-CoV-2 in human airway epithelial cell cultures and multiple coronaviruses in mice. Sci. Transl. Med. 2020, 12. [CrossRef] [PubMed]

54. Ko, W.C.; Rolain, J.M.; Lee, N.Y.; Chen, P.L.; Huang, C.T.; Lee, P.I.; Hsueh, P.R. Arguments in favour of remdesivir for treating SARS-CoV-2 infections. Int. J. Antimicrob Agents 2020, 55, 105933. [CrossRef]

55. Breining, P.; Frølund, A.L.; Højen, J.F.; Gunst, J.D.; Staerke, N.B.; Saedder, E.; Cases-Thomas, M.; Little, P.; Nielsen, L.P.; Søgaard, O.S.; et al. Camostat mesylate against SARS-CoV-2 and COVID-19-Rationale, dosing and safety. Basic Clin. Pharmacol. Toxicol. 2020, 128, 204-212. [CrossRef]

56. Schmaier, A.H. The contact activation and kallikrein/kinin systems: Pathophysiologic and physiologic activities. J. Thromb Haemost 2016, 14, 28-39. [CrossRef] [PubMed]

57. Bojkova, D.; Klann, K.; Koch, B.; Widera, M.; Krause, D.; Ciesek, S.; Cinatl, J.; Münch, C. Proteomics of SARS-CoV-2-infected host cells reveals therapy targets. Nature 2020, 583, 469-472. [CrossRef] [PubMed]

58. Al Heialy, S.; Hachim, M.Y.; Senok, A.; Gaudet, M.; Abou Tayoun, A.; Hamoudi, R.; Alsheikh-Ali, A.; Hamid, Q. Regulation of Angiotensin- Converting Enzyme 2 in Obesity: Implications for COVID-19. Front. Physiol. 2020, 11, 555039. [CrossRef] [PubMed]

59. Cao, X.; Lu, X.M.; Tuo, X.; Liu, J.Y.; Zhang, Y.C.; Song, L.N.; Cheng, Z.Q.; Yang, J.K.; Xin, Z. Angiotensin-converting enzyme 2 regulates endoplasmic reticulum stress and mitochondrial function to preserve skeletal muscle lipid metabolism. Lipids Health Dis. 2019, 18, 207. [CrossRef] [PubMed] 
60. Fu, Y.; Gaelings, L.; Söderholm, S.; Belanov, S.; Nandania, J.; Nyman, T.A.; Matikainen, S.; Anders, S.; Velagapudi, V.; Kainov, D.E. JNJ872 inhibits influenza A virus replication without altering cellular antiviral responses. Antiviral Res. 2016, $133,23-31$. [CrossRef] [PubMed]

61. Finberg, R.W.; Lanno, R.; Anderson, D.; Fleischhackl, R.; van Duijnhoven, W.; Kauffman, R.S.; Kosoglou, T.; Vingerhoets, J.; Leopold, L. Phase 2b Study of Pimodivir (JNJ-63623872) as Monotherapy or in Combination With Oseltamivir for Treatment of Acute Uncomplicated Seasonal Influenza A: TOPAZ Trial. J. Infect. Dis. 2019, 219, 1026-1034. [CrossRef]

62. Perry, C.M.; Faulds, D. Lamivudine. A review of its antiviral activity, pharmacokinetic properties and therapeutic efficacy in the management of HIV infection. Drugs 1997, 53, 657-680. [CrossRef]

63. Antiviral Combination Database. Available online: http:/ / antiviralcombi.info/ (accessed on 31 December 2020).

64. Zusinaite, E.; Ianevski, A.; Niukkanen, D.; Poranen, M.M.; Bjoras, M.; Afset, J.E.; Tenson, T.; Velagapudi, V.; Merits, A.; Kainov, D.E. A Systems Approach to Study Immuno- and Neuro-Modulatory Properties of Antiviral Agents. Viruses 2018, 10, 423. [CrossRef] [PubMed]

65. Ianevski, A.; Yao, R.; Lysvand, H.; Grodeland, G.; Legrand, N.; Oksenych, V.; Zusinaite, E.; Tenson, T.; Bjoras, M.; Kainov, D.E. Nafamostat-Interferon-alpha Combination Suppresses SARS-CoV-2 Infection In Vitro and In Vivo by Cooperatively Targeting Host TMPRSS2. Viruses 2021, 13, 1768. [CrossRef] [PubMed]

66. Schloer, S.; Brunotte, L.; Mecate-Zambrano, A.; Zheng, S.; Tang, J.; Ludwig, S.; Rescher, U. Drug synergy of combinatory treatment with remdesivir and the repurposed drugs fluoxetine and itraconazole effectively impairs SARS-CoV-2 infection in vitro. Br. J. Pharmacol. 2021, 178, 2339-2350. [CrossRef] [PubMed]

67. Matos, A.D.R.; Wunderlich, K.; Schloer, S.; Schughart, K.; Geffers, R.; Seders, M.; Witt, M.; Christersson, A.; Wiewrodt, R.; Wiebe, K.; et al. Antiviral potential of human IFN-alpha subtypes against influenza A H3N2 infection in human lung explants reveals subtype-specific activities. Emerg. Microbes Infect. 2019, 8, 1763-1776. [CrossRef] [PubMed]

68. Wang, E.Y.; Mao, T.; Klein, J.; Dai, Y.; Huck, J.D.; Jaycox, J.R.; Liu, F.; Zhou, T.; Israelow, B.; Wong, P.; et al. Diverse Functional Autoantibodies in Patients with COVID-19. Nature 2021, 595, 283-288. [CrossRef] [PubMed]

69. Bastard, P.; Rosen, L.B.; Zhang, Q.; Michailidis, E.; Hoffmann, H.H.; Zhang, Y.; Dorgham, K.; Philippot, Q.; Rosain, J.; Beziat, V.; et al. Autoantibodies against type I IFNs in patients with life-threatening COVID-19. Science 2020, 370, 1252-1255. [CrossRef] [PubMed]

70. Bessiere, P.; Wasniewski, M.; Picard-Meyer, E.; Servat, A.; Figueroa, T.; Foret-Lucas, C.; Coggon, A.; Lesellier, S.; Boue, F.; Cebron, N.; et al. Intranasal type I interferon treatment is beneficial only when administered before clinical signs onset in the SARS-CoV-2 hamster model. PLoS Pathog. 2021, 17, e1009427. [CrossRef]

71. Kalil, A.C.; Mehta, A.K.; Patterson, T.F.; Erdmann, N.; Gomez, C.A.; Jain, M.K.; Wolfe, C.R.; Ruiz-Palacios, G.M.; Kline, S.; Regalado Pineda, J.; et al. Efficacy of interferon beta-1a plus remdesivir compared with remdesivir alone in hospitalised adults with COVID-19: A double-bind, randomised, placebo-controlled, phase 3 trial. Lancet Respir. Med. 2021, 9, 1365-1376. [CrossRef] 